\title{
Tracking climate change in Central Asia through temperature and precipitation extremes
}

\author{
ZHANG Man ${ }^{1,2},{ }^{*}$ CHEN Yaning ${ }^{2}$, SHEN Yanjun ${ }^{3}$, LI Baofu ${ }^{4}$
}

1. College of Resources and Environmental Science, Hebei Normal University, Shijiazhuang 050024, China;

2. State Key Laboratory of Desert and Oasis Ecology, Xinjiang Institute of Ecology and Geography, CAS, Urumqi 830011, China;

3. Key Laboratory of Agricultural Water Resources, Center for Agricultural Resources Research, CAS, Shijiazhuang 050021, China;

4. College of Geography and Tourism, Qufu Normal University, Rizhao 276826, Shandong, China

\begin{abstract}
Under the impacts of climate change and human activities, great uncertainties still exist in the response of climate extremes, especially in Central Asia (CA). In this study, we investigated spatial-temporal variation trends and abrupt changes in 17 indices of climate extremes, based on daily climate observations from 55 meteorological stations in CA during 1957-2005. We also speculated as to which atmospheric circulation factors had the greatest impacts on climate extremes. Our results indicated that the annual mean temperature (Tav), mean maximum and minimum temperature significantly increased at a rate of $0.32^{\circ} \mathrm{C} / 10 \mathrm{a}$, $0.24^{\circ} \mathrm{C} / 10 \mathrm{a}$ and $0.41^{\circ} \mathrm{C} / 10 \mathrm{a}$, respectively, which was far higher than the increasing rates either globally or across the Northern Hemisphere. Other temperature extremes showed widespread significant warming trends, especially for those indices derived from daily minimum temperature. All temperature extremes exhibited spatially widespread rising trends. Compared to temperature changes, precipitation extremes showed higher spatial and temporal variabilities. The annual total precipitation significantly increased at a rate of 4.76 $\mathrm{mm} / 10 \mathrm{a}$, and all precipitation extremes showed rising trends except for annual maximum consecutive dry days (CDD), which significantly decreased at a rate of -3.17 days/10a. On the whole, precipitation extremes experienced slight wetter trends in the Tianshan Mountains, Kazakhskiy Melkosopochnik (Hill), the Kyzylkum Desert and most of Xinjiang. The results of Cumulative Deviation showed that Tav and Txav had a significant abrupt change around 1987 , and all precipitation indices experienced abrupt changes in 1986. Spearman's correlation analysis pointed to Siberian High and Tibetan Plateau Index_B as possibly being the most important atmospheric circulation factors affecting climate extremes in CA. A full quantitative understanding of these changes is crucial for the management and mitigation of natural hazards in this region.
\end{abstract}

Keywords: abrupt change; atmospheric circulation; climate change; climate extremes; spatial-temporal variability; Central Asia

Received: 2018-02-07 Accepted: 2018-05-30

Foundation: National Natural Science Foundation of China, No.41630859; The CAS "Light of West China" Program, No.2015-XBQN-B-17

Author: Zhang Man, PhD, specialized in extreme climate events in arid areas. E-mail: zhangman14@mails.ucas.ac.cn

"Corresponding author: Chen Yaning, $\mathrm{PhD}$ and Professor, specialized in water resources and ecological hydrological processes in arid areas. E-mail: chenyn@ms.xjb.ac.cn 


\section{Introduction}

Extreme climate events (ECEs) such as droughts, floods, frosts and heat waves can have devastating impacts on natural ecosystems. They can also have a severe impact on social life and economic development, and have thus received heightened attention recently from researchers (Karl and Easterling, 1999; Easterling et al., 2000; Trenberth et al., 2015; Alexander et al., 2016; Diffenbaugh et al., 2017). The latest findings reveal that ECEs have increased both in frequency and intensity over the past few decades, more or less in tangent with human-induced climate change (Alexander et al., 2006; IPCC, 2012; IPCC, 2013; Zhang et al., 2013; Westra et al., 2013; Kim et al., 2016; Stott, 2016). However, there remains some uncertainty as to the response of ECEs, especially in arid regions like Central Asia (CA) (Lioubimtseva and Henebry, 2009; Herold et al., 2017). A better understanding of climate extremes is required if ECEs are to be appropriately researched.

$\mathrm{CA}$ is of exceptional interest to scientists from the perspective of meteorology and hydrology. Being one of the driest regions in the world, CA is not only more sensitive to climate change, but also shrouded in uncertainty with regards to the region's natural response to changing climate (Lioubimtseva et al., 2005; Li et al., 2015b; Zhang et al., 2017). The poor continuity of station-based daily meteorological observations in CA's five countries has resulted in a lack of research on ECEs and climate extremes. Other studies have utilized data from grids, soil, and tree rings (Klein Tank et al., 2006; Schiemann et al., 2008; Chen et al., 2009; Lioubimtseva and Henebry, 2009; Yatagai et al., 2012; Li et al., 2015b), but these data tend either to underestimate or overestimate the frequency and intensity of ECEs (King et al., 2013; Mannig et al., 2013; Hu et al., 2016). Furthermore, as one of the core areas of China's 'Belt and Road' Initiative (Silk Road Economic Belt and 21st-Century Maritime Silk Road, first introduced by the Chinese government in 2013), CA has received increasing interest from the international scientific community, with many research projects focusing on the environmental and ecological variations in the region (Li et al., 2015a; Chen et al., 2016; Howard and Howard, 2016; Li et al., 2016b; Frachetti et al., 2017; Li et al., 2017). Despite the notable uptick in attention, however, information about variation trends of climate extremes or about their possible influencing factors and effects on ecological and social systems remains scarce.

To fill this gap, some researchers have begun looking into the impact of ECEs variations, especially in relation to anthropogenic forcing (Zhang et al., 2013; Kim et al., 2016; Stott, 2016; Stott et al., 2016; Chen and Sun, 2017; Diffenbaugh et al., 2017). At the same time, investigations also need to consider the influence of atmospheric circulations and other natural factors on climate extremes. Recent studies by Chen et al. (2008) and Bothe et al. (2012) revealed that precipitation in CA was mainly affected by the strength of the westerly jet stream, while Wei et al. (2017) demonstrated that changes to out-of-phase rainfall among the five countries in CA and northern China were closely related to the southeast-northwest movements of the South Asian High and the Asian westerly jet stream in 1958-2002. Furthermore, Cheng et al. (2016) found that the millennial-scale climate events occurring in CA (from the Tonnel'naya cave, Uzbekistan and the Kesang cave, western China) were closely coupled with the Asian monsoon and westerly jet stream. Additionally, Zhang et al. (2002) showed the influence of East-Asian monsoons on drought in northwest China; Li et al. 
(2012) noted that the weakening of the Siberian High was a crucial reason for rapid temperature increase in northwestern China from the 1980s to the 1990s; Chen et al. (2014) found that climate extremes had strong and significant relationships with the Tibetan Plateau Index_B (TPI_B) in northwestern China in 1961-2010; and Li et al. (2016a), in continuing the research on the relationships between precipitation and atmospheric circulations, suggested that the West Pacific Subtropical High and the North American Subtropical High were probably the main cause for precipitation variations in northwestern China after the mid-1980s.

Despite their many contributions to the field, these studies have limitations. For instance, some of them focused only on detecting associations between the mean temperature or mean precipitation and atmospheric circulations, without looking at possible associations between climate extremes and atmospheric circulations. Moreover, they studied regional areas within $\mathrm{CA}$, such as only the five countries of CA or northwestern China, but did not investigate CA as a whole. Therefore, in this paper, we use station-based daily climate observations over the course of 49 years (1957-2005) to study spatial-temporal variation trends and abrupt changes in climate extremes in CA. Given that large-scale atmospheric circulation generally determines temperature and precipitation trends (Trenberth et al., 2015; Li et al., 2016a), we tried instead to detect factors impacting atmospheric circulation, which then influence climate extremes in CA.

As water vapour in $\mathrm{CA}$ can originate from northern Eurasia, the western Atlantic, the Arctic Ocean, the eastern Pacific Ocean and the southern Indian Ocean, we selected ten relevant atmospheric circulations for our study, namely the Antarctic Oscillation (AAO), Arctic Oscillation (AO), North Atlantic Oscillation (NAO), Northern Oscillation Index (NOI), Pacific Decadal Oscillation (PDO), Pacific-North American pattern (PNA), Siberian High (SH), Southern Oscillation (SO), Tibetan Plateau Index_B (TPI_B), and Westerly Circulation Index (WCI). As well, we investigated the statistical relationships between 17 extreme climate indices (ECIs) and the 10 chosen atmospheric circulations. The findings on climate extremes under the context of climate change will be of great importance for ecological protection and regional economic development in CA.

\section{Study area, data, and methodology}

\subsection{Study area}

In this study, CA refers to the vast area $\left(5.65\right.$ million $\left.\mathrm{km}^{2}\right)$ generally confined to $45^{\circ}-96^{\circ} \mathrm{E}$ and $35^{\circ}-55^{\circ} \mathrm{N}$, covering five Russian-speaking countries (Kazakhstan, Kyrgyzstan, Tajikistan, Turkmenistan and Uzbekistan) and the Xinjiang Uygur Autonomous Region of China (Xinjiang) (Figure 1). The geomorphological landscapes of the five countries in CA are mainly desert and grasslands, and include the Kyzylkum Desert, the Karakum Desert, etc. Meanwhile, the geomorphology in Xinjiang is characterized by a basin-and-range pattern. The Altai Mountains, Tianshan Mountains, and Kunlun Mountains are located in the northern, middle, and southern parts of the region, respectively, with the Junggar Basin and Tarim Basin positioned between these mountains. The Taklimakan Desert, which is the world's second largest mobile desert, is located in the Tarim Basin. The Tianshan Mountains, known as the 'water tower of Central Asia', feature one of the highest concentrations of glaciers 
globally. These glaciers provide the main water source for people living in the region (Aizen et al., 2006; Pritchard, 2017).

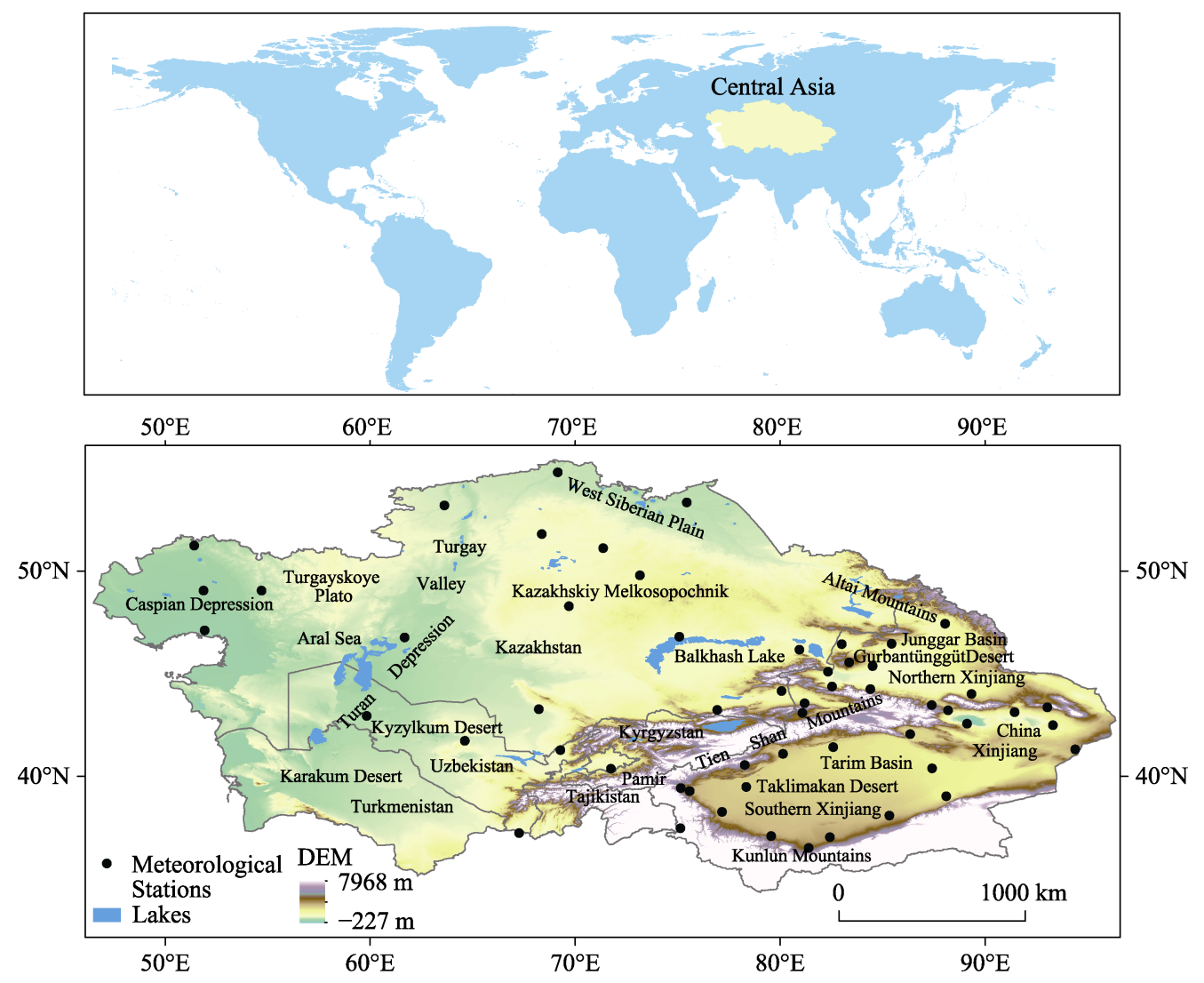

Figure 1 Location of Central Asia and the meteorological stations

As one of the world's most arid areas, CA has a typical temperate continental climate characterized by sharp temperature differences, intensive evaporation, and dry and rainless environments (Lioubimtseva and Henebry, 2009; Li et al., 2015b). The climatic characteristics of CA are determined by location and topography. Since it is located in the hinterland of Eurasia, a long distance away from any sea or ocean, very little moisture reaches this region. This is the main reason for the dry climate. Precipitation is concentrated in spring and winter, due to the influence of the westerly jet stream and the North Atlantic Oscillation. The western and northwestern plains of CA are primarily influenced by moist westerly Atlantic air masses and cold northerly and north-westerly inflows, while the Himalayas, Tibetan Plateau and Pamirs form a natural barrier to the south, cutting off CA from most of the water vapor from the Indian Ocean (Schiemann et al., 2008; Bothe et al., 2012). In the Xinjiang region, northern Xinjiang is primarily affected by water vapor from the Atlantic and Arctic Oceans, but southern Xinjiang receives little moisture from the Indian Ocean, with the Tianshan Mountains and Tibetan Plateau acting as barriers. Due to the location and water shortage, CA has an extremely fragile natural environment and ecological system, which is extremely sensitive to climate change (Lioubimtseva and Henebry, 2009). All these in turn lead to the increases in the frequency and intensity of extreme climate events and the rises in the natural disaster risks. 


\subsection{Data and quality control}

Taking into consideration the unique climate characteristics of CA, we selected for our study 10 extreme temperature indices (Tav, Txav, Tnav, FD0, ID0, SU25, TXx, TXn, TNx, TNn) and 7 extreme precipitation indices (Prcptot, CDD, CWD, R10mm, R20mm, Rx1 day, Rx5 day) (Table 1) from 27 ECIs introduced by the CCl/CLIVAR/JCOMM Expert Team on Climate Change Detection and Indices (ETCCDI) (http://etccdi.pacificclimate.org/list_27_ indices.shtml).

Table 1 Definitions of 17 extreme climate indices chosen for this study

\begin{tabular}{|c|c|c|c|}
\hline Index & Indicator name & Definitions & Units \\
\hline Tav & Mean Tmean & Annual mean temperature & ${ }^{\circ} \mathrm{C}$ \\
\hline Txav & Mean Tmax & Annual average daily maximum temp & ${ }^{\circ} \mathrm{C}$ \\
\hline Tnav & Mean Tmin & Annual average daily minimum temp & ${ }^{\circ} \mathrm{C}$ \\
\hline FD0 & Frost days & Annual count when $\mathrm{TN}$ (daily minimum) $<0^{\circ} \mathrm{C}$ & days \\
\hline ID0 & Ice days & Annual count when $\mathrm{TX}$ (daily maximum) $<0^{\circ} \mathrm{C}$ & days \\
\hline SU25 & Summer days & Annual count when $\mathrm{TX}$ (daily maximum) $>25^{\circ} \mathrm{C}$ & days \\
\hline TXx & Max Tmax & Monthly maximum value of daily maximum temp & ${ }^{\circ} \mathrm{C}$ \\
\hline $\mathrm{TNx}$ & Max Tmin & Monthly maximum value of daily minimum temp & ${ }^{\circ} \mathrm{C}$ \\
\hline TXn & Min Tmax & Monthly minimum value of daily maximum temp & ${ }^{\circ} \mathrm{C}$ \\
\hline $\mathrm{TNn}$ & Min Tmin & Monthly minimum value of daily minimum temp & ${ }^{\circ} \mathrm{C}$ \\
\hline Prcptot & $\begin{array}{l}\text { Annual total wet-day } \\
\text { precipitation }\end{array}$ & Annual total precipitation in wet days $(\mathrm{RR} \geqslant 1 \mathrm{~mm})$ & $\mathrm{mm}$ \\
\hline CDD & Consecutive dry days & Annual maximum number of consecutive days with $\mathrm{RR}<1 \quad \mathrm{~mm}$ & days \\
\hline CWD & Consecutive wet days & Annual maximum number of consecutive days with $\mathrm{RR} \geqslant 1 \mathrm{~mm}$ & days \\
\hline $\mathrm{R} 10 \mathrm{~mm}$ & $\begin{array}{l}\text { Number of heavy pre- } \\
\text { cipitation days }\end{array}$ & Annual count of days when $R R \geqslant 10 \mathrm{~mm}$ & days \\
\hline $\mathrm{R} 20 \mathrm{~mm}$ & $\begin{array}{l}\text { Number of very heavy } \\
\text { precipitation days }\end{array}$ & Annual count of days when $R R \geqslant 20 \mathrm{~mm}$ & days \\
\hline Rx1 day & $\begin{array}{l}\text { Max 1-day precipitation } \\
\text { amount }\end{array}$ & Monthly maximum 1-day precipitation & $\mathrm{mm}$ \\
\hline Rx5 day & $\begin{array}{l}\text { Max 5-day precipitation } \\
\text { amount }\end{array}$ & Monthly maximum consecutive 5-day precipitation & $\mathrm{mm}$ \\
\hline
\end{tabular}

Detail definitions of extreme climate indices can be checked on the ETCCDMI website: http:/etccdi.pacificclimate. org/list_27_indices.shtml. All indices are calculated by R ClimDex. Temp denotes temperature. RR represents daily precipitation.

Continuous station-based temperature and precipitation data can greatly improve the research accuracy of climate extremes. Courtesy of the National Oceanic and Atmospheric Administration (NOAA), we downloaded the daily temperature and precipitation records of 568 meteorological stations in the five CA countries (Menne et al., 2012). These records are original datasets and have not undergone quality control. As well, daily observation datasets from 68 meteorological stations in Xinjiang were collected from the China Meteorological Data Service Center (CMDC), but these datasets had undergone the strict quality control and inspection procedures of the CMDC. Additionally, we obtained data from 10 circulation indices (AAO, AO, NAO, NOI, PDO, PNA, SH, SOI, TPI_B, WCI_DJF) (WCI_DJF denotes WCI in December, January and February) from China's National Climate Center 
(http://cmdp.ncc.cma.gov.cn/cn/download.htm), and the Earth System Research Laboratory (ESRL) (https://www.esrl.noaa.gov/psd/data/climateindices/list/).

To carry out data quality control on the raw datasets, we used the R ClimDex software package (R ClimDex) (http://etccdi.pacificclimate.org/software.shtml) (Zhang and Feng, 2004), which performed error-detection on these data, such as days with $T \max <$ Tmin or daily precipitation below $0 \mathrm{~mm}$, and searched for outliers. We chose five standard deviations as thresholds to avoid mistaking the real value as outliers and to obtain better data quality. The datasets from stations that were missing more than $5 \%$ of relevant data were discarded. Overall, across the five CA countries, only 22 meteorological stations were suitable for use in this study due to numerous gaps, whereas in Xinjiang, 33 meteorological stations were suitable (Figure 1). Thus, based on a grand total of 55 meteorological stations, we investigated 17 ECIs during 1957-2005 through R ClimDex.

\subsection{Method}

We used the arithmetic mean values of each ECI from the 55 stations during 1957-2005 as the representative value of $\mathrm{CA}$ to reflect the temporal variations of climate extremes in this study (Liu et al., 2014). Regional annual anomaly series and linear regression were conducted to reflect the extent of temporal variations for ECIs.

As the Mann-Kendall non-parametric trend test (MK test) (Mann, 1945; Kendall, 1975) does not need to follow a certain sample distribution and is not affected by the interference of a few outliers, it has been widely used in the research fields of meteorological and hydrological time series variation. In this study, we conducted MK tests based on the values of each ECI to detect the temporal variation trends and significant levels for all stations across CA. Twenty-year overlapping time windows (Zhang et al., 2017) were also utilized to analyze the temporal changing trends of 17 extreme indices in the region during 1957-2005 (for a total of 30 windows in 49 years). Furthermore, we applied Cumulative Deviation (Buishand, 1982) to detect abrupt changes in ECIs based on the mean values of the whole region, after which the Student's t test (Dugmore et al., 2007) was conducted to analyze the mean level of ECIs at the two stages within the time before and time after the abrupt changes. Finally, we employed Spearman's correlation analysis (Nunes and Lourenço, 2015), which is a non-parametric test, to investigate the statistical relationships between the 17 ECIs and 10 atmospheric circulations.

\section{Analysis and results}

\subsection{Variation trends and abrupt changes in temperature extremes}

\subsubsection{Temporal patterns of Tav, Txav and Tnav}

The Tav, Txav and Tnav indices are useful for reflecting the variation trends of the mean, maximum and minimum temperatures, respectively. On the whole, the Tav, Txav and Tnav indices during 1957-2005 for CA all showed a significant increasing trend, with Tnav exhibiting larger increases than Tav or Txav (Table 2, Figures $2 \mathrm{e}-2 \mathrm{~g}$ and $3 \mathrm{a}-3 \mathrm{c}$ ). The MK test results revealed that Tav, Txav and Tnav significantly increased $(p<0.01)$ at rates of $0.032^{\circ} \mathrm{C} / \mathrm{a}, 0.024^{\circ} \mathrm{C} / \mathrm{a}$ and $0.041^{\circ} \mathrm{C} / \mathrm{a}$, respectively. The increase in Tav, Txav and Tnav 
points to a notable warming trend in CA, which is consistent with widespread global warming during the same time period.

Table 2 Temporal variation trends of extreme temperature indices based on MK test during 1957-2005 in CA

\begin{tabular}{|c|c|c|c|c|c|c|c|c|}
\hline \multirow[b]{2}{*}{ Index } & \multicolumn{4}{|c|}{ MK test } & \multirow{2}{*}{$\begin{array}{l}\text { Percentage } \\
\text { of stations } \\
\text { showing } \\
\text { increasing } \\
\text { trend }\end{array}$} & \multirow{2}{*}{$\begin{array}{c}\text { Percentage } \\
\text { of stations } \\
\text { showing } \\
\text { significant } \\
\text { increasing } \\
\text { trend }\end{array}$} & \multirow{2}{*}{$\begin{array}{l}\text { Percentage } \\
\text { of stations } \\
\text { showing } \\
\text { decreasing } \\
\text { trend }\end{array}$} & \multirow{2}{*}{$\begin{array}{c}\text { Percentage } \\
\text { of stations } \\
\text { showing } \\
\text { significant } \\
\text { decreasing } \\
\text { trend }\end{array}$} \\
\hline & Trend rate & Z-value & Trends & $\begin{array}{c}\text { Significance } \\
\text { level (p) }\end{array}$ & & & & \\
\hline Tav & $0.032^{\circ} \mathrm{C} / \mathrm{a}$ & 4.89 & $\uparrow$ & 0.01 & $98.18 \%$ & $94.55 \%$ & $1.82 \%$ & 0 \\
\hline Txav & $0.024^{\circ} \mathrm{C} / \mathrm{a}$ & 3.39 & $\uparrow$ & 0.01 & $100 \%$ & $70.91 \%$ & 0 & 0 \\
\hline Tnav & $0.041^{\circ} \mathrm{C} / \mathrm{a}$ & 5.78 & $\uparrow$ & 0.01 & $98.18 \%$ & $94.55 \%$ & $1.82 \%$ & $1.82 \%$ \\
\hline FD0 & -0.323 days/a & -4.71 & $\downarrow$ & 0.01 & $3.64 \%$ & 0 & $96.36 \%$ & $80.00 \%$ \\
\hline ID0 & -0.187 days/a & -2.31 & $\downarrow$ & 0.05 & $3.64 \%$ & 0 & $96.36 \%$ & $25.45 \%$ \\
\hline SU25 & 0.206 days/a & 3.18 & $\uparrow$ & 0.01 & $96.36 \%$ & $45.45 \%$ & $3.64 \%$ & $1.82 \%$ \\
\hline TXx & $0.020^{\circ} \mathrm{C} / \mathrm{a}$ & 2.67 & $\uparrow$ & 0.01 & $81.82 \%$ & $29.09 \%$ & $18.18 \%$ & $1.82 \%$ \\
\hline $\mathrm{TNx}$ & $0.030^{\circ} \mathrm{C} / \mathrm{a}$ & 5.14 & $\uparrow$ & 0.01 & $87.27 \%$ & $58.18 \%$ & $12.73 \%$ & $1.82 \%$ \\
\hline TXn & $0.059^{\circ} \mathrm{C} / \mathrm{a}$ & 2.38 & $\uparrow$ & 0.05 & $96.36 \%$ & $34.55 \%$ & $3.64 \%$ & 0 \\
\hline $\mathrm{TNn}$ & $0.088^{\circ} \mathrm{C} / \mathrm{a}$ & 3.86 & $\uparrow$ & 0.01 & $100 \%$ & $70.91 \%$ & 0 & 0 \\
\hline
\end{tabular}

The positive value denotes an increasing trend and negative value represents a decreasing trend.

Both Tav and Txav experienced a significant abrupt change around 1987 (Table 3). The mean values of Tav and Txav were $9.09^{\circ} \mathrm{C} / \mathrm{a}$ and $15.31^{\circ} \mathrm{C} / \mathrm{a}$ in $1987-2005$, respectively, up $18.18 \%$ and $4.22 \%$ over 1957-1986. Tnav, however, experienced a significant abrupt change around 1977 , resulting in a mean value in $1977-2005$ of $2.66^{\circ} \mathrm{C} / \mathrm{a}$. This was an increase of $1.08^{\circ} \mathrm{C} / \mathrm{a}$, whereas the average in $1957-1976$ was $1.58^{\circ} \mathrm{C} / \mathrm{a}$. The mean value of Tnav in 1977-2005 increased $68.35 \%$ over $1957-1986$. Thus, Tnav's rising trend was larger than that of Tav or Txav, indicating that the rise in daily minimum temperature made a significant contribution to the warming rate of CA.

\subsubsection{Spatial patterns of Tav, Txav and Tnav}

In 1957-2005, Tav, Txav and Tnav all showed a widespread significant warming trend, especially Tav and Tnav (Figures $2 \mathrm{a}-2 \mathrm{c}$ ). Approximately $98.18 \%$ of the stations showed rising trends for Tav and Tnav, while $94.55 \%$ of the stations showed significant increases. Only one station (located in the northern edge of the Tarim Basin) showed a falling trend, but this was not significant for Tav and Tnav. All (100\%) of the stations showed increasing trends for Txav, but only $70.91 \%$ showed significant increasing trends. These results indicate that spatial variations in Tav, Txav and Tnav were generally consistent with less spatial diversities in CA.

\subsubsection{Temporal patterns of warm extremes (TXx, TNx and SU25)}

As the TXx, TNx and SU25 indices reflect variations in summertime temperatures, they are regarded here as warm extremes. All of the warm extremes showed significant rising trends $\left(\mathrm{p}<0.01\right.$ ), with rates of $0.020^{\circ} \mathrm{C} / \mathrm{a}, 0.030^{\circ} \mathrm{C} / \mathrm{a}$ and 0.206 days $/ \mathrm{a}$, respectively (Figures $3 \mathrm{~d}-3 \mathrm{f}$ and $4 \mathrm{a}-4 \mathrm{c})$. The rate of increase for SU25 indicated that hotter summer days increased rapidly 

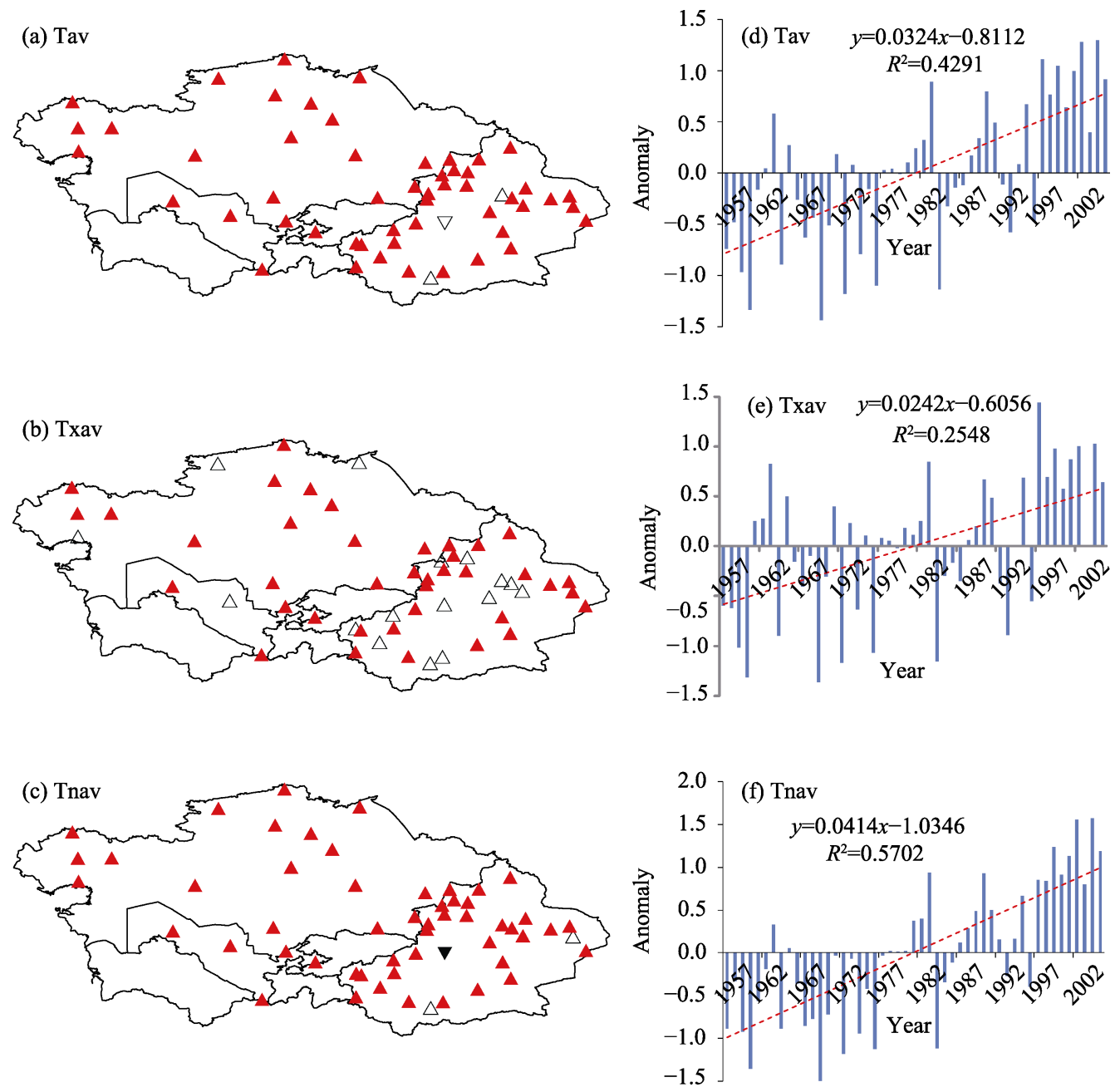

Figure 2 Spatial-temporal variation trends of the extreme temperature indices of Tav, Txav and Tnav during 1957-2005 in Central Asia. (a)-(c): Spatial variation trends of (a) Tav, (b) Txav and (c) Tnav (The red filled triangle denotes significant rising trend $(P<0.05)$; the unfilled triangle denotes rising trend but not significant; the black filled inverted-triangle denotes significant falling trend $(P<0.05)$; the unfilled inverted-triangle denotes falling trend but not significant). (d)-(f): Regional annual anomaly series of (d) Tav, (e) Txav and (f) Tnav (The blue column denotes the annual anomaly series and the red dash line represents the linear regression)

during 1957-2005. Meanwhile, the rising rate of TNx was higher than TXx. The abrupt change in both TNx and SU25 was significant around 1973, and the mean values of TNx and SU25 in $1957-1972$ were $22.72^{\circ} \mathrm{C} / \mathrm{a}$ and 109.55 days/a, respectively, and $23.58^{\circ} \mathrm{C} / \mathrm{a}$ and 115.47 days/a in 1973-2005, respectively. The mean values of TNx and SU25 in 1973-2005 increased by $3.79 \%$ and $5.40 \%$ over $1957-1972$, respectively. 1972 marked a significant abrupt change for TXx, with the mean value measuring $0.78^{\circ} \mathrm{C} / \mathrm{a}$ warmer in $1972-2005$ than in previous years. The mean value of TXx in 1972-2005 increased 2.10\% over 1957-1971.

\subsubsection{Spatial patterns of warm extremes (TXx, TNx and SU25)}

These three indices showed significant increasing trends mainly in the Turgay Valley, Kyzylkum Desert, Kazakhskiy Melkosopochnik, and northern Tianshan Mountains 

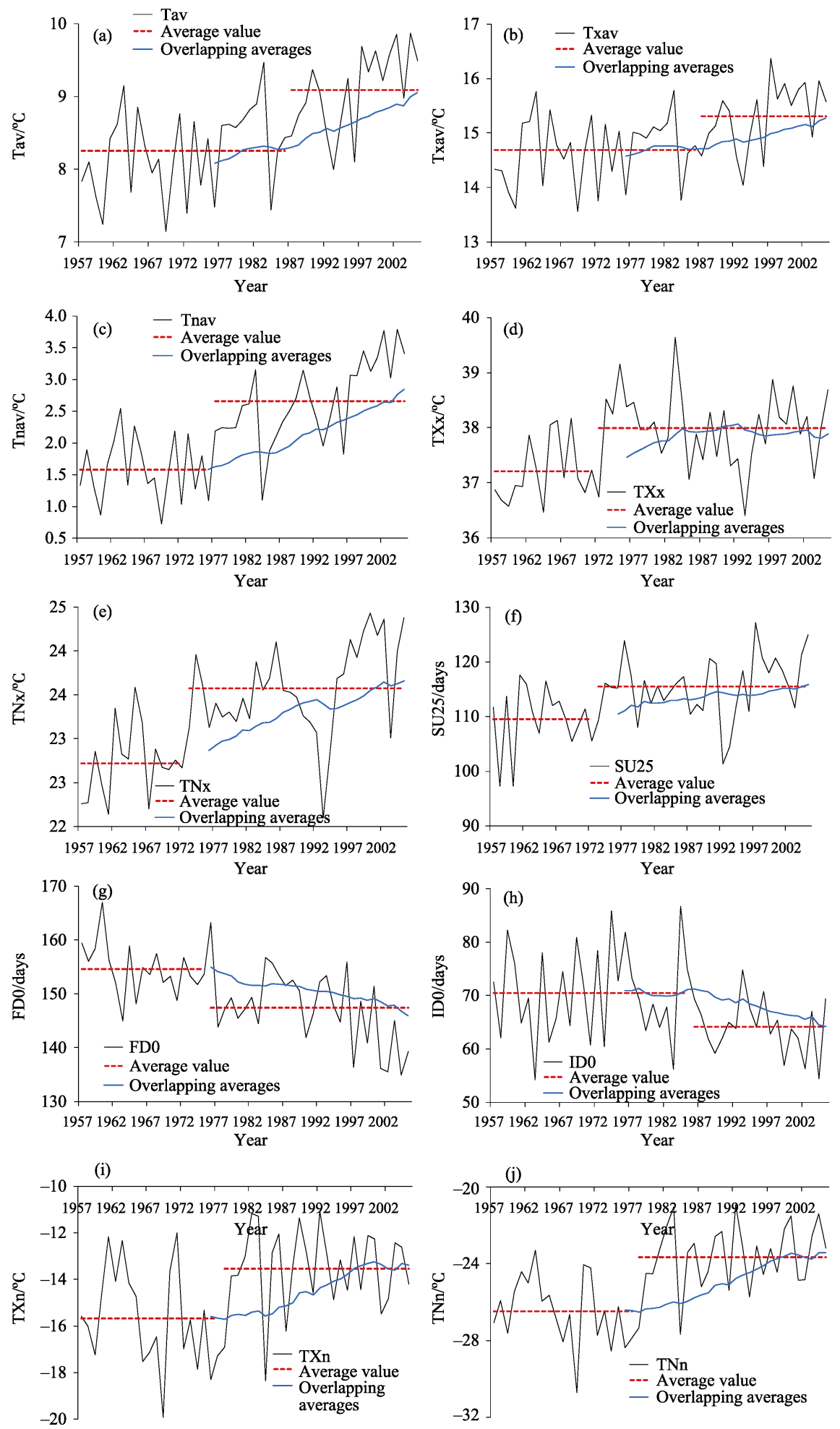

Figure 3 Temporal variation trends of extreme temperature indices during 1957-2005 in CA. (a) Tav, (b) Txav, (c) Tnav, (d) TXx, (e) TNx, (f) SU25, (g) FD0, (h) ID0, (i) TXn and (j) TNn. Red dotted line denotes the mean value of each extreme temperature index before and after abrupt change; Black and blue solid lines represent time series variations and 20 -year overlapping averages for each precipitation indices, respectively. 
Table 3 Abrupt change of extreme temperature indices based on the test results of cumulative deviation and student's t test during 1957-2005 in CA

\begin{tabular}{|c|c|c|c|c|c|}
\hline \multirow{2}{*}{ Index } & \multicolumn{2}{|c|}{ Cumulative deviation } & \multirow{2}{*}{ Period } & \multicolumn{2}{|c|}{ Student's t test } \\
\hline & $\mathrm{Q} / \operatorname{Sqrt}(\mathrm{n})$ & Year of change & & Mean value & P value \\
\hline \multirow{2}{*}{ Tav } & \multirow{2}{*}{$2.02 *$} & \multirow{2}{*}{1987} & $1957-1986$ & $8.25^{\circ} \mathrm{C} / \mathrm{a}$ & \multirow{2}{*}{$-2.87^{*}$} \\
\hline & & & 1987-2005 & $9.09^{\circ} \mathrm{C} / \mathrm{a}$ & \\
\hline \multirow{2}{*}{ Txav } & \multirow{2}{*}{$1.58^{*}$} & \multirow{2}{*}{1987} & 1957-1986 & $14.69^{\circ} \mathrm{C} / \mathrm{a}$ & \multirow{2}{*}{$-2.10^{*}$} \\
\hline & & & 1987-2005 & $15.31^{\circ} \mathrm{C} / \mathrm{a}$ & \\
\hline \multirow{2}{*}{ Tnav } & \multirow{2}{*}{$2.36^{*}$} & \multirow{2}{*}{1977} & 1957-1976 & $1.58^{\circ} \mathrm{C} / \mathrm{a}$ & \multirow{2}{*}{$-3.71 *$} \\
\hline & & & 1977-2005 & $2.66^{\circ} \mathrm{C} / \mathrm{a}$ & \\
\hline \multirow{2}{*}{ FD0 } & \multirow{2}{*}{$1.97 *$} & \multirow{2}{*}{1976} & $1957-1975$ & 154.59 days/a & \multirow{2}{*}{$3.50 *$} \\
\hline & & & 1976-2005 & 147.41 days/a & \\
\hline \multirow{2}{*}{ ID0 } & \multirow{2}{*}{$1.37^{*}$} & \multirow{2}{*}{1986} & $1957-1985$ & 70.43 days/a & \multirow{2}{*}{$2.69 *$} \\
\hline & & & 1986-2005 & 64.17 days/a & \\
\hline \multirow[b]{2}{*}{ SU25 } & \multirow[b]{2}{*}{$1.55^{*}$} & \multirow[b]{2}{*}{1973} & $1957-1972$ & 109.55 days/a & \multirow[b]{2}{*}{$-3.24 *$} \\
\hline & & & 1973-2005 & 115.47 days/a & \\
\hline \multirow{2}{*}{ TXx } & \multirow{2}{*}{$1.80^{*}$} & \multirow{2}{*}{1972} & $1957-1971$ & $37.21^{\circ} \mathrm{C} / \mathrm{a}$ & \multirow{2}{*}{$-2.53 *$} \\
\hline & & & $1972-2005$ & $37.99^{\circ} \mathrm{C} / \mathrm{a}$ & \\
\hline \multirow{2}{*}{$\mathrm{TNx}$} & \multirow{2}{*}{$2.17^{*}$} & \multirow{2}{*}{1973} & $1957-1972$ & $22.72^{\circ} \mathrm{C} / \mathrm{a}$ & \\
\hline & & & 1973-2005 & $23.58^{\circ} \mathrm{C} / \mathrm{a}$ & $-2.81^{*}$ \\
\hline & & & $1957-1977$ & $-15.67^{\circ} \mathrm{C} / \mathrm{a}$ & \\
\hline TXn & $1.85^{*}$ & 1978 & 1978-2005 & $-13.53^{\circ} \mathrm{C} / \mathrm{a}$ & $-3.71 *$ \\
\hline & & & 1957-1977 & $-26.48^{\circ} \mathrm{C} / \mathrm{a}$ & \\
\hline TNn & $2.35^{*}$ & 1978 & $1978-2005$ & $-23.65^{\circ} \mathrm{C} / \mathrm{a}$ & $-4.89 *$ \\
\hline
\end{tabular}

Trends significant (significance level<0.05) are marked with *.

(Figures 5a-5c). Meanwhile, $8.18 \%$ of the stations showed a decreasing trend for TXx, which was mainly distributed around the south and southwest edges of the Tarim Basin. For TNx and SU25, $87.27 \%$ and $96.36 \%$ of the stations showed increasing trends, respectively, and $58.18 \%$ and $45.45 \%$ of the stations had significant increases.

\subsubsection{Temporal patterns of cold extremes (FD0, ID0, TXn and TNn)}

The FD0, ID0, TXn and TNn indices exhibit temperature changes of cold days and cold nights, so they are regarded as cold extremes here. On the whole, all of the cold extremes during 1957-2005 in CA showed significant changing trends and faster warming rates than the indices of warm extremes (Figures $3 \mathrm{~g}-3 \mathrm{j}$ ). FD0 showed a significant decreasing trend $(\mathrm{p}<0.01)$, at a rate of -0.323 days/a, while ID0 displayed a significant decreasing trend $(\mathrm{p}<0.05)$, at a rate of -0.187 days/a (Figures $4 \mathrm{~d}-4 \mathrm{e})$. Meanwhile, TXn significantly increased $(\mathrm{p}<0.05)$, at a rate of $0.059^{\circ} \mathrm{C} / \mathrm{a}$, while TNn notably increased $(\mathrm{p}<0.01)$, at a rate of $0.088^{\circ} \mathrm{C} / \mathrm{a}$ (Figures $4 \mathrm{f}-4 \mathrm{~g}$ ). From the above, we can see that the rising rates of cold extremes (TXn and $\mathrm{TNn}$ ) were more than twice higher than warm extremes (TXx and TNx). This is similar to Tnav, whose increasing rates were also approximately twice that of Txav. Therefore, the warming rates of daily minimum temperatures were higher than daily maximum temperatures, and the faster warming rates of cold extremes were the most important driving force in CA's climate warming. 

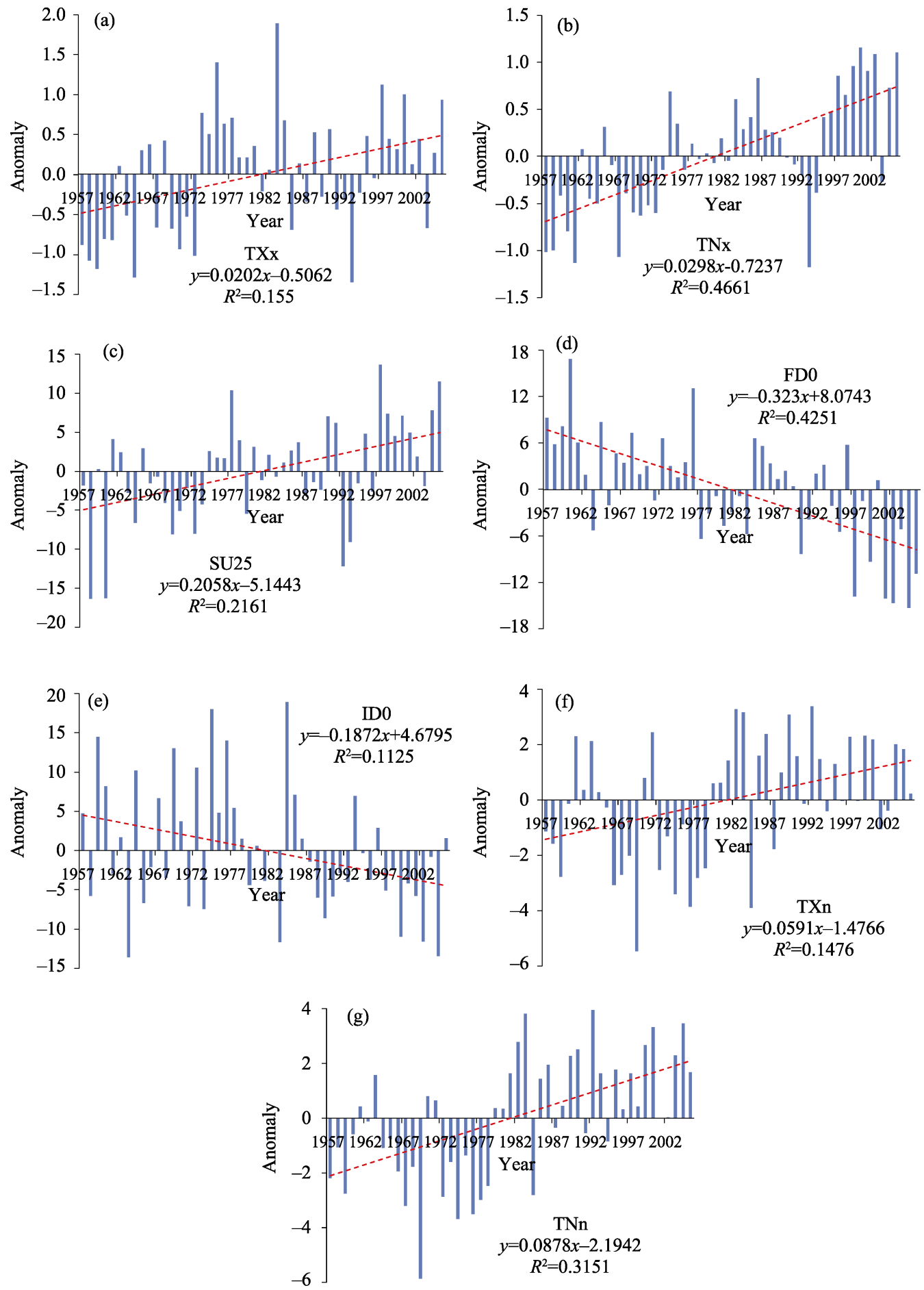

Figure 4 Regional annual anomaly series for each extreme temperature indices. The blue column denotes the annual anomaly series and the red dash line represents the linear regression. (a) TXx, (b) TNx, (c) SU25, (d) FD0, (e) ID0, (f) TXn and (g) TNn.

Abrupt changes in FD0 occurred around in 1976, with the mean value 7.18 days/a shorter in 1975-2005 than before. The mean value of FD0 in 1976-2005 increased by $4.64 \%$ over 

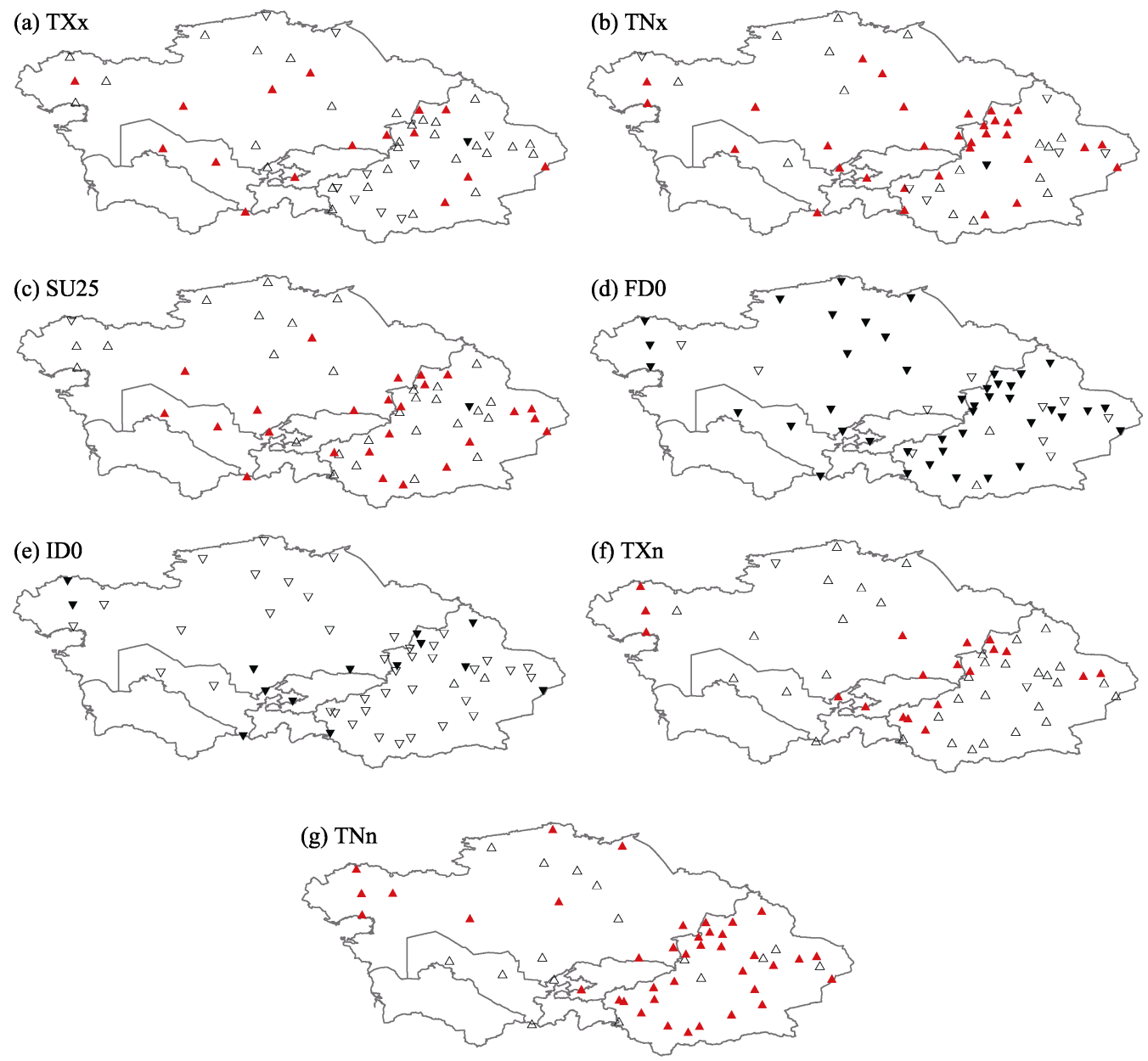

Figure 5 Spatial variation trends of the extreme temperature indices (a) TXx, (b) TNx, (c) SU25, (d) FD0, (e) ID0, (f) TXn and (g) TNn. The red filled triangle denotes significant rising trend $(P<0.05)$; the unfilled triangle denotes rising trend but not significant; the black filled inverted-triangle denotes significant falling trend $(p<0.05)$; the unfilled inverted-triangle denotes falling trend but not significant.

1957-1975. An abrupt change for ID0 occurred in 1986, decreasing 6.26 days/a during 1986-2005 compared to previous years. The mean value of ID0 in 1986-2005 increased by $8.89 \%$ over 1957-1985. Significant abrupt changes were also detected in 1978 for both TXn and $\mathrm{TNn}$, increasing $2.14^{\circ} \mathrm{C} / \mathrm{a}$ and $2.83^{\circ} \mathrm{C} / \mathrm{a}$, respectively, during $1978-2005$ than before. The mean values of TXn and TNn in 1978-2005 increased by $13.66 \%$ and $10.69 \%$ over 1957-1977, respectively.

\subsubsection{Spatial patterns of cold extremes (FD0, ID0, TXn and TNn)}

FD0 and ID0 showed widespread falling trends across the entire region of CA. Both FD0 and ID0 showed falling trends at $96.36 \%$ of stations, but $80 \%$ of the stations showed significant decreases for FD0, while only $25.45 \%$ of the stations showed significant decreases for ID0. There was a significant decreasing trend for FD0 in most of CA, except for two isolated stations located at the edge of the Tarim Basin, where an insignificant increasing trend was observed (Figure 5d). For ID0, the stations showing significant decreasing trends were located in southern CA (five countries) and west of northern Xinjiang (Figure 5e). TXn 
and $\mathrm{TNn}$ showed increasing trends at $96.36 \%$ and $100 \%$ of the stations, respectively, but $70.91 \%$ of the stations showed a significant rising trend for TNn and only $34.55 \%$ showed significant increases for TXn. In fact, significant increases of TXn mainly occurred in the Caspian Depression and around the Tianshan Mountains (Figure 5f). The entire region of CA showed widespread rising trends for TNN, with significant increases occurring mainly in the Caspian Depression, West Siberian Plain, and across most of Xinjiang (Figure 5g).

\subsection{Variation trends and abrupt changes in precipitation extremes}

\subsubsection{Temporal patterns of Prcptot, CDD and CWD}

These three precipitation indices reflect the changing trends of total wet and dry conditions in CA. The results of the MK test revealed that Prcptot exhibited a significant rising trend $(p<0.05)$ at a rate of $0.476 \mathrm{~mm} / \mathrm{a}$ during 1957-2005 (Table 4, Figures $6 \mathrm{~d}$ and $7 \mathrm{a}$ ), while CDD displayed a significant falling trend $(p<0.05)$ at a rate of -0.317 days/a (Figures $6 \mathrm{e}$ and $7 b$ ) and CWD showed a non-significant increasing trend at a rate of 0.001 days/a (Figures $6 f$ and 7c). All three indices experienced the same abrupt change year (around 1986), but the abrupt change was significant only for Prcptot and CDD (Table 5). The mean values of Prcptot and CWD were $164.88 \mathrm{~mm} / \mathrm{a}$ and 3.09 days/a in 1986-2005, respectively, increasing $17.63 \mathrm{~mm} / \mathrm{a}$ and 0.10 days/a. The mean value of CDD was 103.10 days/a in 1986-2005, decreasing 10.39 days/a. The mean values of Prcptot and CWD in 1986-2005 increased by $11.97 \%$ and $3.34 \%$ over $1957-1985$, respectively. For CDD, the mean value in 1986-2005 decreased by $9.15 \%$ over $1957-1985$.

Table 4 Temporal variation trend of extreme precipitation indices based on the results of MK test during 1957-2005 in CA

\begin{tabular}{|c|c|c|c|c|c|c|c|c|}
\hline \multirow[b]{2}{*}{ Index } & \multicolumn{4}{|c|}{ MK test } & \multirow{2}{*}{$\begin{array}{l}\text { Percentage } \\
\text { of stations } \\
\text { showing } \\
\text { increasing } \\
\text { trend (\%) }\end{array}$} & \multirow{2}{*}{$\begin{array}{l}\text { Percentage } \\
\text { of stations } \\
\text { showing } \\
\text { significant } \\
\text { increasing } \\
\text { trend }(\%)\end{array}$} & \multirow{2}{*}{$\begin{array}{l}\text { Percentage } \\
\text { of stations } \\
\text { showing } \\
\text { decreasing } \\
\text { trend (\%) }\end{array}$} & \multirow{2}{*}{$\begin{array}{c}\text { Percentage } \\
\text { of stations } \\
\text { showing } \\
\text { significant } \\
\text { decreasing } \\
\text { trend (\%) }\end{array}$} \\
\hline & Trend rate & Z-value & Trends & $\begin{array}{l}\text { Significance } \\
\text { level (p) }\end{array}$ & & & & \\
\hline Prcptot & $0.476 \mathrm{~mm} / \mathrm{a}$ & 2.11 & $\uparrow$ & 0.05 & 81.82 & 25.45 & 18.18 & 1.82 \\
\hline CDD & -0.317 days $/ \mathrm{a}$ & -2.26 & $\downarrow$ & 0.05 & 21.82 & 1.82 & 78.18 & 5.45 \\
\hline CWD & 0.001 days/a & 0.28 & $\uparrow$ & NS & 49.09 & 3.64 & 50.91 & 0 \\
\hline $\mathrm{R} 10 \mathrm{~mm}$ & 0.016 days/a & 2.19 & $\uparrow$ & 0.05 & 76.36 & 12.73 & 23.64 & 1.82 \\
\hline $\mathrm{R} 20 \mathrm{~mm}$ & 0.004 days/a & 1.94 & $\uparrow$ & 0.1 & 69.09 & 5.45 & 30.91 & 0 \\
\hline Rx1 day & $0.040 \mathrm{~mm} / \mathrm{a}$ & 2.14 & $\uparrow$ & 0.05 & 69.09 & 9.09 & 30.91 & 1.82 \\
\hline Rx5 day & $0.055 \mathrm{~mm} / \mathrm{a}$ & 1.50 & $\uparrow$ & NS & 65.45 & 10.91 & 34.55 & 3.64 \\
\hline
\end{tabular}

The positive value denotes increasing trend and negative value represents decreasing trend.

\subsubsection{Spatial patterns of Prcptot, CDD and CWD}

Comparing temperature changes, Prcptot, CDD and CWD were generally less consistent and significant, and showed higher spatial diversity and heterogeneity across the entire study area. Rising trends for Prcptot were observed at $81.82 \%$ of the stations, although among these only $25.45 \%$ showed significant rises, and these stations were mainly located in the eastern Tianshan Mountains (in Xinjiang) (Figure 6a). Meanwhile, 18.18\% of the stations had falling trends for Prcptot and most of these stations were located in the Caspian Depression, 
Table 5 Abrupt change of extreme precipitation indices based on the test results of cumulative deviation and student's $t$ test for extreme precipitation indices during 1957-2005 in CA

\begin{tabular}{|c|c|c|c|c|c|}
\hline \multirow{2}{*}{ Index } & \multicolumn{2}{|c|}{ Cumulative deviation } & \multirow{2}{*}{ Periods } & \multicolumn{2}{|c|}{ Student's t test } \\
\hline & $\mathrm{Q} / \mathrm{Sqrt}(\mathrm{n})$ & Year of change & & Mean value & $P$ value \\
\hline \multirow[t]{2}{*}{ Prcptot } & $1.44 *$ & 1986 & $1957-1985$ & $147.25 \mathrm{~mm} / \mathrm{a}$ & $-2.64 *$ \\
\hline & & & $1986-2005$ & $164.88 \mathrm{~mm} / \mathrm{a}$ & \\
\hline \multirow[t]{2}{*}{ CDD } & $1.58 *$ & 1986 & $1957-1985$ & 113.49 days/a & $2.75^{*}$ \\
\hline & & & $1986-2005$ & 103.10 days/a & \\
\hline \multirow[t]{2}{*}{ CWD } & 0.81 & 1986 & $1957-1985$ & 2.99 days/a & $-\infty *$ \\
\hline & & & $1986-2005$ & 3.09 days/a & \\
\hline \multirow[t]{2}{*}{$\mathrm{R} 10 \mathrm{~mm}$} & $1.41 *$ & 1986 & $1957-1985$ & 3.24 days/a & -1.94 \\
\hline & & & $1986-2005$ & 3.80 days/a & \\
\hline \multirow[t]{2}{*}{$\mathrm{R} 20 \mathrm{~mm}$} & $1.39 *$ & 1986 & $1957-1985$ & 0.67 days/a & $-\infty *$ \\
\hline & & & $1986-2005$ & 0.82 days/a & \\
\hline \multirow[t]{2}{*}{ Rx1 day } & $1.60^{*}$ & 1986 & $1957-1985$ & $17.80 \mathrm{~mm} / \mathrm{a}$ & $-2.57 *$ \\
\hline & & & $1986-2005$ & $19.29 \mathrm{~mm} / \mathrm{a}$ & \\
\hline \multirow[t]{2}{*}{ Rx5 day } & $1.52 *$ & 1986 & $1957-1985$ & $25.79 \mathrm{~mm} / \mathrm{a}$ & $-2.84 *$ \\
\hline & & & $1986-2005$ & $28.27 \mathrm{~mm} / \mathrm{a}$ & \\
\hline
\end{tabular}

Trends significant (significance level<0.05) are marked with *.

Turgay Valley and south of Kazakhstan. For CDD, 78.18\% of the stations experienced decreasing trends. Only $5.45 \%$ of the stations showed significant decreasing trends. These stations were located in the Kyzylkum Desert and southern Xinjiang, which indicated that the number of dry days had significantly decreased in these areas (Figure 6b). The southwest of Kazakhskiy Melkosopochnik, however, showed significant increases for CDD. Meanwhile, in most areas across CA, CWD showed a falling trend in all five countries as well as west of northern Xinjiang, but rising trends in most of southern Xinjiang (Figure 6c).

\subsubsection{Temporal patterns of R10mm, R20mm, Rx1 day and $\mathrm{Rx} 5$ day}

These four indices were used to show the frequency and intensity of precipitation extremes. Both R10mm (R10) and Rx1 day (Rx1) showed significant increasing trends, with rates of 0.016 days/a and $0.040 \mathrm{~mm} / \mathrm{a}$, respectively (Figures 7d, 7f, 8a and 8c). R20mm (R20) and $\mathrm{Rx} 5$ day $(\mathrm{Rx} 5)$ had non-significant rising trends, with rates of 0.004 days/a and 0.055 $\mathrm{mm} / \mathrm{a}$, respectively (Figures $7 \mathrm{e}, 7 \mathrm{~g}, 8 \mathrm{~b}$ and $8 \mathrm{~d}$ ). Rx1 showed a significant increasing trend but Rx5 did not, which suggested that the intensity of daily precipitation had strengthened during 1957-2005. For all four of the indices (R10, R20, Rx1, Rx5), 1986 marked an abrupt change. R10 and R20 were 3.80 days/a and 0.82 days/a in 1986-2005, respectively, when the mean values were 0.56 days/a and 0.15 days/a longer than previously. Furthermore, the mean values of Rx1 and Rx5 were $19.29 \mathrm{~mm} / \mathrm{a}$ and $28.27 \mathrm{~mm} / \mathrm{a}$ in 1986-2005, respectively, increasing $1.49 \mathrm{~mm} / \mathrm{a}$ and $2.48 \mathrm{~mm} / \mathrm{a}$ over prior readings. The mean values of R10, R20, $\mathrm{Rx} 1$ and $\mathrm{Rx} 5$ in 1986-2005 increased by $17.28 \%, 22.39 \%, 8.37 \%$ and $9.62 \%$ over 1957-1985, respectively.

\subsubsection{Spatial patterns of R10, R20, Rx1 and Rx5}

Consistent with Prcptot, CDD and CWD outlined above, R10mm, R20mm, Rx1 day and 
(a) Prcptot

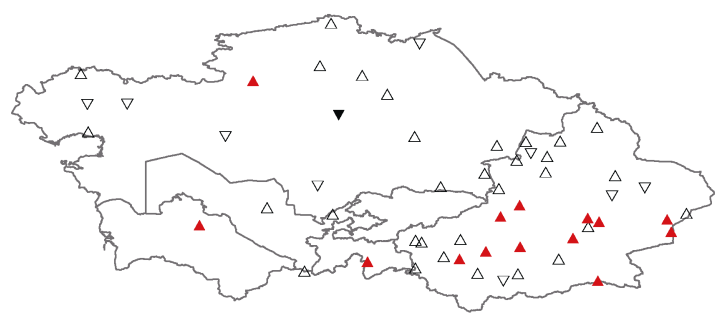

(b) CDD

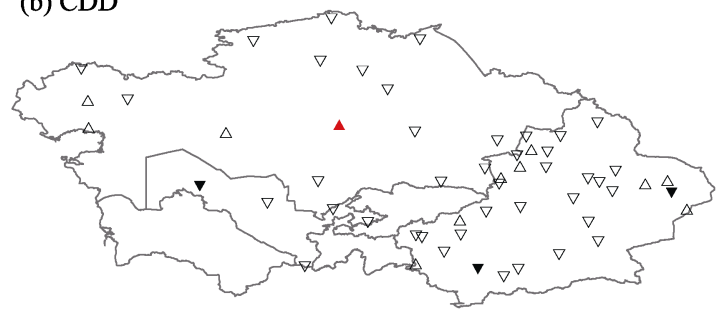

(c) CWD

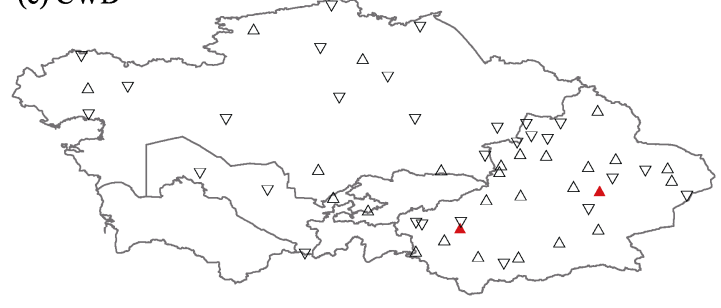

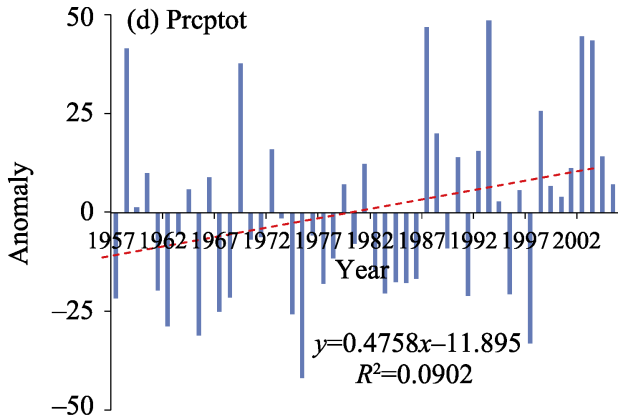
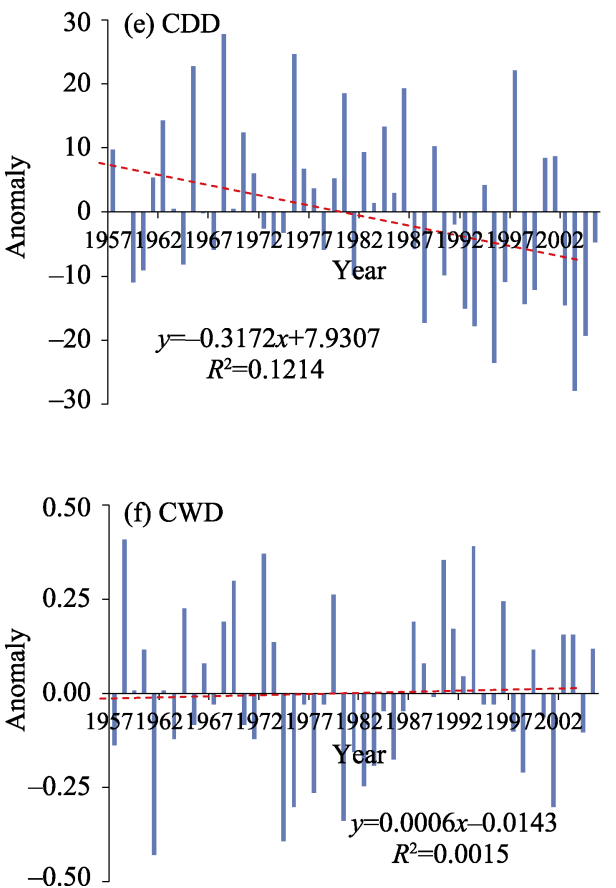

Figure 6 Spatial-temporal variation trends of the extreme precipitation indices of Prcptot, CDD and CWD during 1957-2005 in Central Asia. (a)-(c): Spatial variation trends of (a) Prcptot, (b) CDD and (c) CWD. (The red filled triangle denotes significant rising trend $(P<0.05)$; the unfilled triangle denotes rising trend but not significant; the black filled inverted-triangle denotes significant falling trend $(P<0.05)$; the unfilled inverted-triangle denotes falling trend but not significant). (d)-(f): Regional annual anomaly series of (d) Prcptot, (e) CDD and (f) CWD (The blue column denotes the annual anomaly series and the red dash line represents the linear regression).

Rx5 day also showed higher spatial diversity and heterogeneity across the entire area under study. For R10, $76.36 \%$ of the stations experienced a rising trend, but only $12.73 \%$ showed a significant rising trend, and most of those stations were located in southern Xinjiang (Figure 9a). For R20, 30.91\% of the stations showed decreasing trends and were mainly in the north of Kazakhstan and the northernmost areas of northern Xinjiang (Figure 9b). Rx1 showed rising trends at $69.09 \%$ of the stations (mainly in Xinjiang and western Kazakhstan) but showed falling trends at $30.91 \%$ of the stations (mainly in Kazakhskiy Melkosopochnik and southern Kazakhstan) (Figure 9c). For Rx5, 65.45\% of the stations showed rising trends, $34.55 \%$ exhibited falling trends, and only $10.91 \%$ showed significant increasing trends, with most of the latter stations being located in Xinjiang (Figure 9d). 

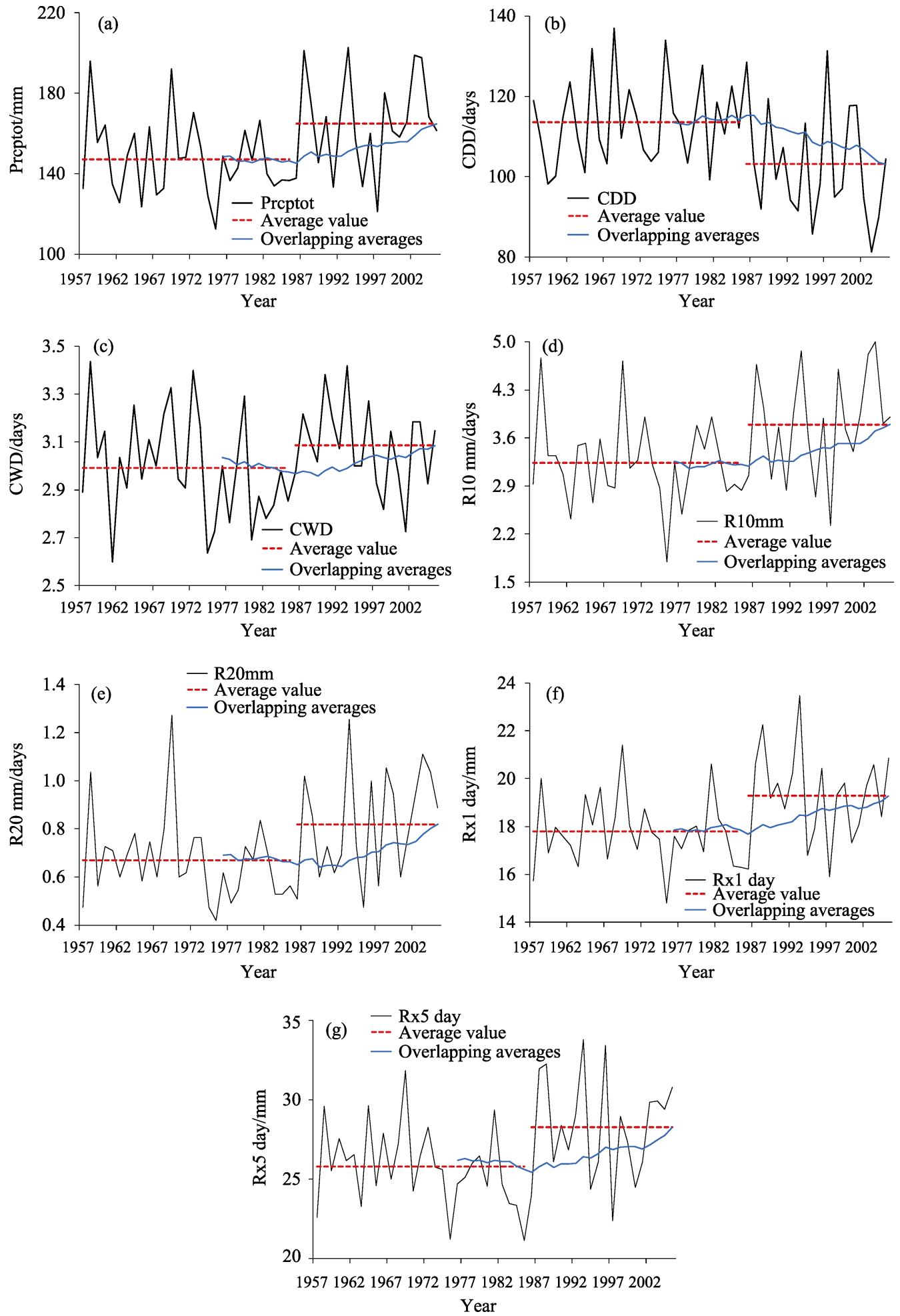

Figure 7 Temporal variation trends of extreme precipitation indices during 1957-2005 in CA. (a) Prcptot, (b) CDD, (c) CWD, (d) R10mm, (e) R20mm, (f) Rx1 day and (g) Rx5 day. Red dotted line denotes the mean value of each extreme temperature indices before and after abrupt change; Black and blue solid lines represent time series variations and 20-year overlapping averages for each precipitation indices, respectively. 

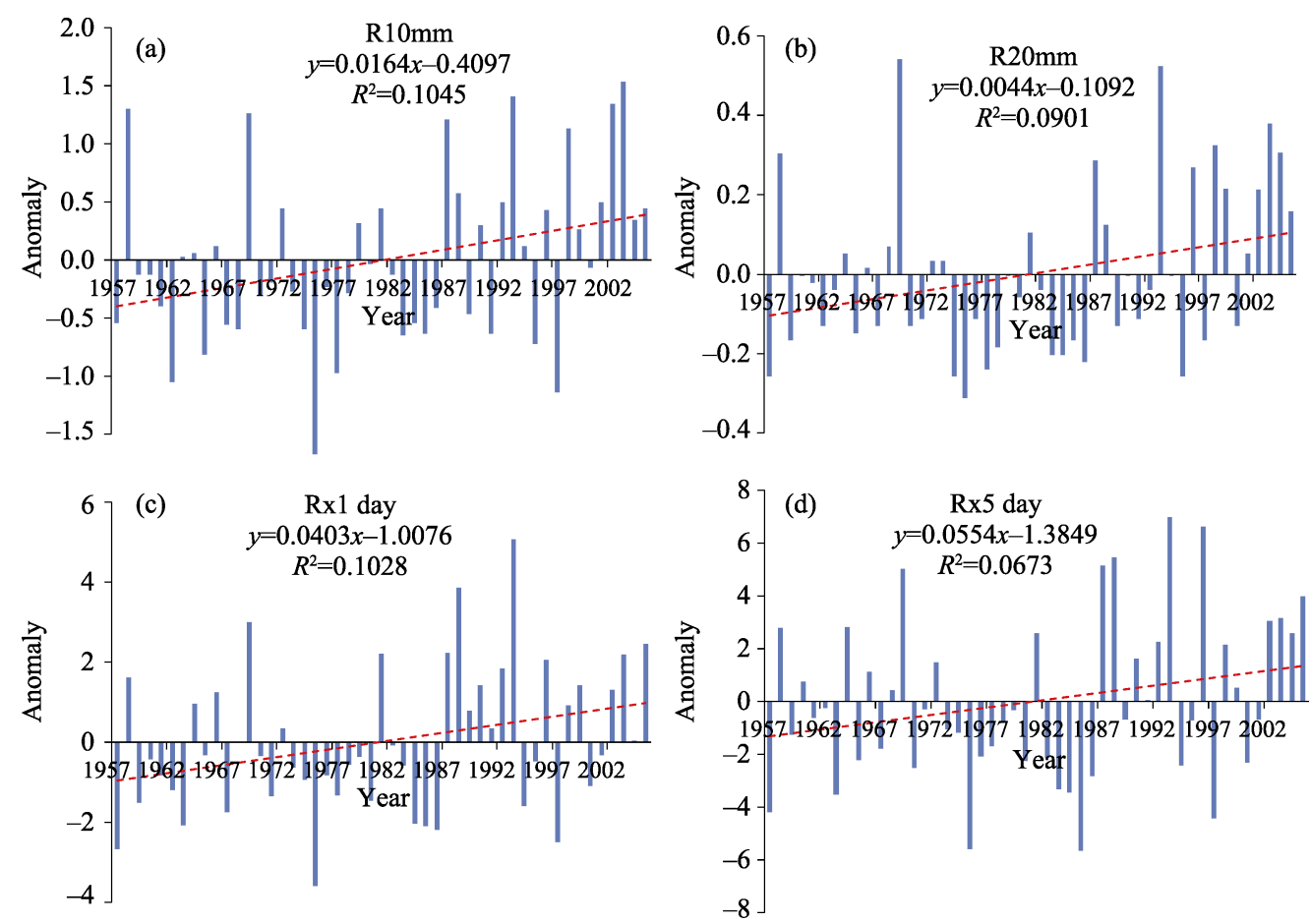

Figure 8 Regional annual anomaly series for each extreme precipitation indices. The blue column denotes the annual anomaly series and the red dash line represents the linear regression. (a) R10mm, (b) R20mm, (c) Rx1 day and (d) Rx5 day.

(a) $\mathrm{R} 10 \mathrm{~mm}$

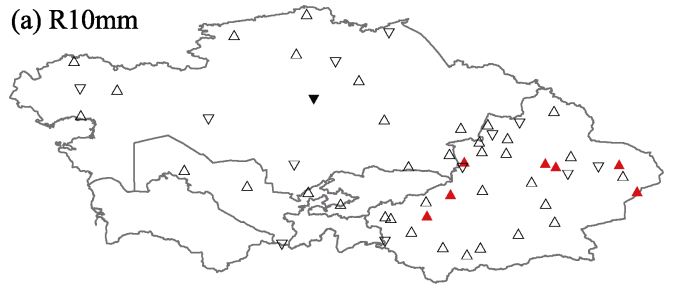

(c) Rx1 day

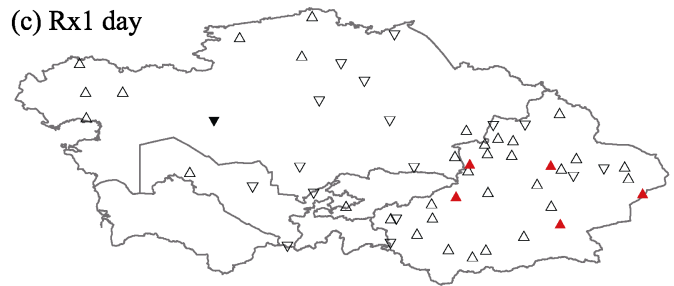

(b) R20mm

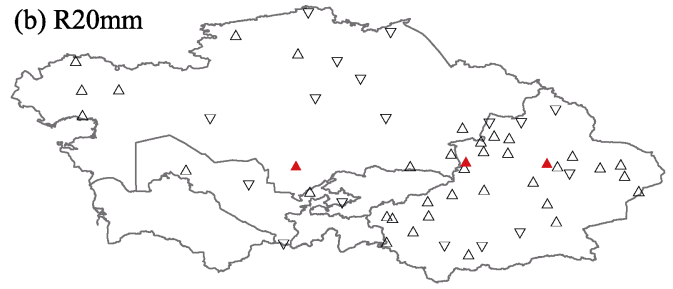

(d) $\operatorname{Rx} 5$ day

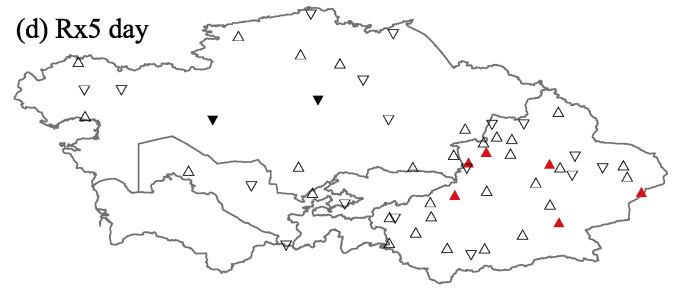

Figure 9 Spatial variation trends of the extreme precipitation indices (a) R10mm, (b) R20mm, (c) Rx1 day, (d) Rx5 day. The red filled triangle denotes significant rising trend $(\mathrm{P}<0.05)$; the unfilled triangle denotes rising trend but not significant; the black filled inverted-triangle denotes significant falling trend $(\mathrm{P}<0.05)$; the unfilled inverted-triangle denotes falling trend but not significant.

\subsection{Possible atmospheric circulation factors influencing climate extremes}

Spearman's correlation analysis was conducted to investigate the statistical relationships between the 17 climate extremes and 10 atmospheric circulations (AAO, AO, NAO, NOI, PDO, PNA, SH, SO, TPI_B and WCI) in CA. The results showed that, in 1957-2005, SH 
and WCI had significant correlations with temperature extremes (Table 6), while TPI_B and PNA showed good consistency with precipitation extremes (Table 7). SH showed significant correlation with Tav, Txav, Tnav, FD0, ID0, TXn, TNn and Prcptot (correlation coefficient $\mathrm{R}=-0.415,-0.331,-0.457,0.320,0.507,-0.350,-0.365$ and -0.313 , respectively), and WCI exhibited significant correlation with Tav, Tnav, FD0, TXn and TNn ( $\mathrm{R}=0.402,0.485$, $-0.382,0.347$, and 0.394 , respectively). TPI_B had good consistency with Tav, Tnav, ID0, Prcptot, CDD, CWD, R10, R20, Rx1 and Rx5 (R =0.312, 0.326, -0.377, 0.531, -0.422, $0.311,0.516,0.568,0.344$ and 0.451 , respectively), whereas PNA had significant correlation with Prcptot, CDD, R10, R20mm, Rx1, Rx5 ( $\mathrm{R}=0.359,-0.312,0.324,0.300,0.342$ and 0.315 , respectively).

Table 6 The correlation coefficient values between temperature extremes in CA and atmospheric circulations

\begin{tabular}{|c|c|c|c|c|c|c|c|c|c|c|}
\hline \multirow{2}{*}{$\begin{array}{l}\text { Circulation } \\
\text { index }\end{array}$} & \multicolumn{10}{|c|}{ Indices } \\
\hline & Tav & Txav & Tnav & FD0 & ID0 & SU25 & TXx & $\mathrm{TNx}$ & TXn & $\mathrm{TNn}$ \\
\hline $\mathrm{AAO}$ & 0.153 & 0.216 & 0.139 & -0.049 & -0.144 & 0.078 & -0.074 & 0.153 & 0.179 & 0.182 \\
\hline $\mathrm{AO}$ & 0.247 & 0.194 & 0.272 & -0.145 & -0.157 & 0.112 & 0.092 & 0.028 & $0.336^{*}$ & 0.271 \\
\hline NAO & -0.053 & -0.062 & 0.003 & 0.079 & 0.070 & 0.089 & -0.059 & -0.104 & 0.158 & 0.099 \\
\hline NOI & -0.166 & -0.046 & -0.260 & 0.264 & 0.143 & 0.125 & 0.054 & 0.055 & -0.119 & -0.228 \\
\hline PDO & 0.085 & -0.101 & 0.217 & -0.150 & 0.013 & -0.002 & 0.089 & 0.235 & 0.160 & $0.310^{*}$ \\
\hline PNA & 0.171 & 0.085 & 0.248 & -0.230 & -0.143 & 0.038 & 0.098 & 0.137 & 0.088 & 0.214 \\
\hline $\mathrm{SH}$ & $\begin{array}{c}-0.415^{*} \\
*\end{array}$ & $\begin{array}{c}-0.331 \\
*\end{array}$ & $-0.457 * *$ & $0.320^{*}$ & $0.507 * *$ & 0.066 & 0.004 & -0.005 & -0.350 * & $-0.365^{*}$ \\
\hline SOI & -0.172 & -0.071 & -0.254 & $0.317^{*}$ & 0.058 & -0.061 & 0.074 & 0.057 & 0.010 & -0.094 \\
\hline TPI_B & $0.312 *$ & 0.281 & $0.326^{*}$ & -0.254 & $-0.377 * *$ & 0.028 & -0.129 & 0.073 & 0.022 & 0.120 \\
\hline WCI_DJF $^{\mathrm{c}}$ & $0.402 * *$ & 0.277 & $0.485 * *$ & $-0.382^{*}$ & -0.265 & 0.266 & -0.042 & 0.300 & $0.347 *$ & $0.394 * *$ \\
\hline
\end{tabular}

** Significant at $\mathrm{p}<0.01$; Significant at $\mathrm{p}<0.05$. WCI_DJF denotes WCI in December, January and February.

Table 7 The correlation coefficient values between precipitation extremes in CA and atmospheric circulations

\begin{tabular}{cccccccc}
\hline \multirow{2}{*}{$\begin{array}{c}\text { Circulation } \\
\text { index }\end{array}$} & \multicolumn{7}{c}{ Indices } \\
\cline { 2 - 7 } & Prcptot & CDD & CWD & R10mm & R20mm & Rx1 day & Rx5 day \\
\hline AAO & -0.039 & 0.024 & -0.102 & -0.115 & 0.115 & -0.112 & -0.149 \\
AO & -0.048 & -0.139 & 0.045 & -0.038 & -0.113 & -0.045 & -0.077 \\
NAO & -0.115 & -0.012 & -0.089 & -0.099 & -0.245 & -0.119 & -0.185 \\
NOI & -0.218 & 0.097 & -0.127 & -0.261 & -0.143 & -0.218 & -0.059 \\
PDO & 0.252 & -0.246 & 0.056 & 0.243 & 0.094 & 0.226 & 0.146 \\
PNA & $0.359^{*}$ & $-0.312^{*}$ & 0.039 & $0.324 *$ & $0.300^{*}$ & $0.342^{*}$ & $0.315^{*}$ \\
SH & $-0.313 *$ & 0.170 & -0.204 & -0.265 & -0.232 & -0.199 & -0.131 \\
SOI & -0.191 & 0.063 & -0.123 & -0.191 & -0.126 & -0.170 & -0.070 \\
TPI-B & $0.531 * *$ & $-0.422^{* *}$ & $0.311^{*}$ & $0.516^{* *}$ & $0.568 * *$ & $0.344^{*}$ & $0.451^{* *}$ \\
WCI_DJF & 0.117 & -0.269 & 0.195 & 0.082 & 0.015 & 0.212 & 0.258 \\
\hline
\end{tabular}

** Significant at $\mathrm{p}<0.01 ;$ * Significant at $\mathrm{p}<0.05$. WCI_DJF denotes WCI in December, January and February.

From the preceding, we can see that both SH and TPI_B had significant correlation $(\mathrm{p}<0.05)$ with Tav, Tnav and Prcptot. SH had significant correlation $(\mathrm{p}<0.05)$ with 7 temperature extremes and strong correlation $(\mathrm{p}<0.01)$ with 3 temperature extremes. TPI_B showed good consistency $(\mathrm{p}<0.05)$ with all 7 precipitation extremes in this study and sig- 
nificant correlation $(\mathrm{p}<0.01)$ with 5 of them. WCI was highly correlated with $\operatorname{Tav}(\mathrm{p}<0.01)$, but not with Prcptot $(\mathrm{p}>0.05)$. PNA had significant correlation with Prcptot $(\mathrm{p}>0.05)$, but not with Tav $(\mathrm{p}>0.05)$. Based on these findings, we speculate that SH and TPI_B were the most important atmospheric circulation factors influencing the temperature and precipitation extremes of CA during 1957-2005.

From Figures 10a and 10b, we can see that TPI_B had a minimum value in 1984. TPI_B showed a decreasing trend prior to 1984, but afterwards showed an overall increasing trend. Except for CDD, which had significant negative correlation with TPI_B, all of the other extreme precipitation indices had strong positive correlations with TPI_B. The temporal variation tendency of TPI_B matched the extreme indices of precipitation, and most of the correlation coefficient values were at $0.40-0.50$. Figures $10 \mathrm{c}$ and $10 \mathrm{~d}$ showed that $\mathrm{SH}$ had significant positive correlations only with FD0 and ID0 and significant negative correlations with Tav, Txav, Tnav, TXn and TNn. Compared with the correlations between TPI_B and precipitation extremes, SH had only a few with these temperature extremes due to the variation trends of fluctuations not matching well (i.e., most of the correlation coefficient values were at $0.30-0.40)$.
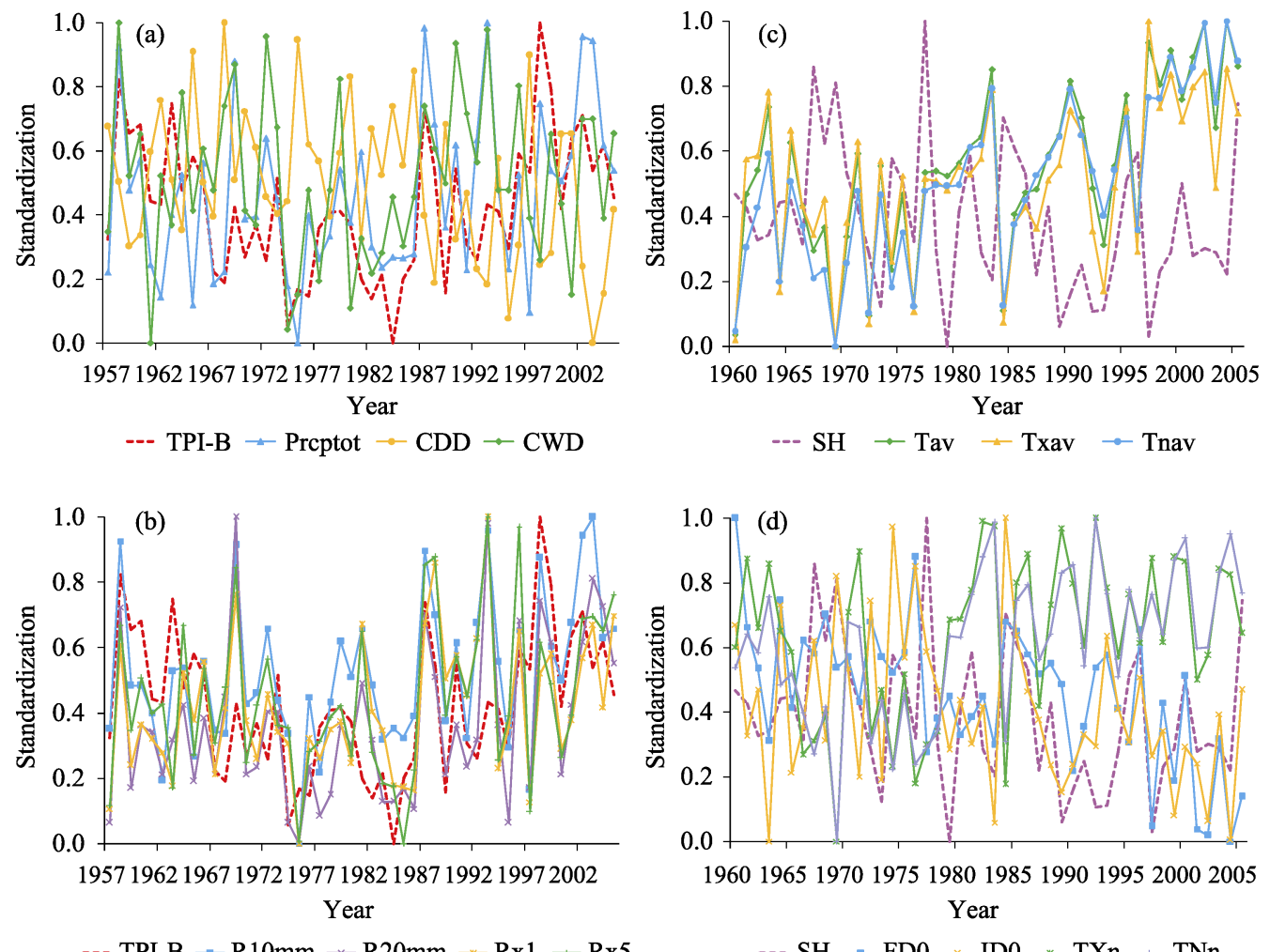

Figure 10 Time series variations between TPI_B and extreme precipitation indices (a)-(b); and between SH and extreme temperature indices (c)-(d)

\section{Discussion}

The last three decades have been the warmest on record since the late 19th century, which for many researchers indicates a sure sign of global warming (Hansen et al., 2010; Jones et 
al., 2012; Morice et al., 2012; IPCC, 2013). The increasing rates of average annual land surface air temperature worldwide and in the Northern Hemisphere are $0.07^{\circ} \mathrm{C} / 10 \mathrm{a}$ and $0.10^{\circ} \mathrm{C} / 10 \mathrm{a}$, respectively (Harris et al., 2014). In China, Tav increased by $0.27^{\circ} \mathrm{C}$ per decade during 1961-2003 (You et al., 2011), while Li et al. (2012), Deng et al. (2014) and Chen et al. (2014) found that Tav increased in arid northwestern China by $0.34^{\circ} \mathrm{C} / 10 \mathrm{a}$ in $1960-2010$, $0.29-0.39^{\circ} \mathrm{C} / 10 \mathrm{a}$ in $1961-2010$, and $0.33^{\circ} \mathrm{C} / 10 \mathrm{a}$ in $1961-2010$, respectively. The present study found that Tav in CA had a significant warming trend at a rate of $0.32^{\circ} \mathrm{C} / 10 \mathrm{a}$ during 1957-2005, which was consistent with the study by $\mathrm{Hu}$ et al. (2014) and close to the increasing rate of northwestern China. The increasing rate of Tav in CA was far higher than the global rate or that of the Northern Hemisphere. This accelerated warming trend in CA again proves that $\mathrm{CA}$ is one of the most sensitive areas to climate change in the world.

The rise in minimum temperature is the main driving force behind climate warming both globally and regionally. In this study, results showed that faster warming trends occurred at extreme temperature indices rooted in daily minimum temperature (Tnav, FD0, TNx and $\mathrm{TNn}$ ); indices derived from daily maximum temperature (Txav, ID0, SU25, TXx and TXn) also showed warming trends, but with smaller magnitudes. These results were in accordance with previous studies (Table 8). For example, the increasing rates of TNx and TNn occurred more quickly than TXX and TXn worldwide (Alexander et al., 2006), in China (You et al., 2011), the Middle East (Zhang et al., 2005), northwestern China (Wang et al., 2013b; Chen et al., 2014), southwestern China (Li et al., 2012), and the eastern and central Tibetan Plateau (You et al., 2008), which revealed a notable reduction in the frequency of extreme low temperatures from global to regional perspectives.

From a global perspective, precipitation extremes showed a general rising trend in the past half-century (Donat et al., 2016). Meanwhile, many studies have been conducted to

Table 8 Trends of extreme temperature indices from this study and other works

\begin{tabular}{|c|c|c|c|c|c|c|c|}
\hline Index & $\begin{array}{c}\text { CA (five } \\
\text { countries and } \\
\text { Xinjiang of } \\
\text { China } \\
(1957-2005)\end{array}$ & $\begin{array}{c}\text { Northwestern } \\
\text { China } \\
(1960-2003)\end{array}$ & $\begin{array}{l}\text { Middle East } \\
(1950-2003)\end{array}$ & $\begin{array}{c}\text { Eastern and } \\
\text { central Tibetan } \\
\text { Plateau } \\
(1961-2005)\end{array}$ & $\begin{array}{c}\text { Southwestern } \\
\text { China } \\
(1961-2008)\end{array}$ & $\begin{array}{c}\text { China } \\
(1961-2003)\end{array}$ & $\begin{array}{c}\text { Global } \\
(1951-2003)\end{array}$ \\
\hline Tav & $4.89 *$ & $5.45 *$ & & & & & \\
\hline Txav & $3.39 *$ & $3.96^{*}$ & & & & & \\
\hline Tnav & $5.78 *$ & $6.77 *$ & & & & & \\
\hline FD0 & $-4.71 *$ & $-3.24 *$ & -0.6 & $-4.32 *$ & $-0.29 *$ & $-3.73 *$ & \\
\hline ID0 & $-2.31 *$ & $-2.75^{*}$ & & $-2.46^{*}$ & -0.09 & & \\
\hline SU25 & $3.18 *$ & & 1 & & & & \\
\hline TXx & $2.67 *$ & 0.17 & 0.07 & $0.28 *$ & $0.11 *$ & 0.07 & $0.21 *$ \\
\hline $\mathrm{TNx}$ & $5.14 *$ & $0.32 *$ & $0.23 *$ & $0.25^{*}$ & $0.17 *$ & $0.21 *$ & 0.30 * \\
\hline TXn & $2.38 *$ & $0.61 *$ & 0.2 & $0.30 *$ & $0.13^{*}$ & $0.35^{*}$ & 0.37 \\
\hline TNn & $3.86^{*}$ & $0.85^{*}$ & $0.28 *$ & $0.69 *$ & $0.29 *$ & $0.63^{*}$ & $0.71 *$ \\
\hline $\begin{array}{l}\text { Data } \\
\text { Source }\end{array}$ & This study & $\begin{array}{l}\text { Wang et al. } \\
(2013 \mathrm{~b}) \text { and } \\
\text { Chen et al } \\
\text { (2014) }\end{array}$ & $\begin{array}{l}\text { Zhang et al. } \\
\quad(2005)\end{array}$ & $\begin{array}{c}\text { You et al. } \\
(2008)\end{array}$ & $\begin{array}{l}\text { Li et al. } \\
(2012)\end{array}$ & $\begin{array}{l}\text { You et al. } \\
\text { (2011) }\end{array}$ & $\begin{array}{c}\text { Alexander } \\
\text { et al. (2006) }\end{array}$ \\
\hline
\end{tabular}

Trends significant (significance level<0.05) are marked with*. 
analyze and estimate the variations of total precipitation and precipitation extremes in arid areas around the world. The variations revealed complex and contrasting trends across arid areas. For example, in northwestern China (Table 9) and western Argentina (Skansi et al., 2013), precipitation extremes exhibited an increasing trend. In the west coast of South America, Prcptot, Rx5 and R20 showed non-significant decreasing trends, while CDD, Rx1 and CWD showed slight increasing trends (Skansi et al., 2013). In Australia, the extreme precipitation indices of simple daily intensity (SDII), very heavy precipitation contribution (R95T) and CDD all were expected to more than double within the next 100 years (Alexander and Arblaster, 2009), whereas in the southwestern United States, total precipitation and flood magnitudes showed that general decreases and droughts had significantly increased (Peterson et al., 2013). Over the Greater Horn of Africa region, there were few significant trends in precipitation extremes except for Prcptot, which showed a significant decrease (Omondi et al., 2014). Prcptot and R10 also consistently showed non-significant decreases and CDD had a general increase over much of the Arabian Peninsula (Donat et al., 2014). In the Middle East, CDD displayed a significant decreasing trend and Prcptot showed a non-significant falling trend (Zhang et al., 2005) In the eastern and central Tibetan Plateau, Prcptot, R10 and Rx1 exhibited a non-significant rising trend, CDD showed a notable falling trend, and CWD charted a falling trend (You et al., 2008). In this study, Prcptot, R10 and Rx1 showed significant rising trends, CDD a notable falling trend, and CWD, R20 and Rx5 non-significant rising trends, all of which reflected increased precipitation and fewer dry days during 1957-2005 in CA. The results of the variations of total precipitation and precipitation extremes in this study were similar with those of other studies during the same time periods (e.g., Lioubimtseva et al., 2005; Klein Tank et al., 2006; Zhang et al., 2017), and were consistent with global changing trends in precipitation extremes.

Table 9 Trends of extreme precipitation indices from this study and other works

\begin{tabular}{|c|c|c|c|c|c|c|c|c|}
\hline Index & $\begin{array}{l}\text { CA (five } \\
\text { countries } \\
\text { and Xin- } \\
\text { jiang of } \\
\text { China) } \\
(1957- \\
2005)\end{array}$ & $\begin{array}{c}\text { CA (five } \\
\text { countries) } \\
(1938- \\
2005)\end{array}$ & $\begin{array}{c}\text { Northwestern } \\
\text { China } \\
(1960-2003)\end{array}$ & $\begin{array}{c}\text { Middle } \\
\text { East } \\
(1950- \\
2003)\end{array}$ & $\begin{array}{c}\text { Eastern and } \\
\text { central } \\
\text { Tibetan } \\
\text { Plateau } \\
(1961- \\
2005)\end{array}$ & $\begin{array}{c}\text { South- } \\
\text { western } \\
\text { China } \\
(1961- \\
2008)\end{array}$ & $\begin{array}{c}\text { China } \\
(1961- \\
2003)\end{array}$ & $\begin{array}{c}\text { Global } \\
(1951- \\
2003)\end{array}$ \\
\hline Prcptot & $2.11^{*}$ & $3.60 *$ & $6.82 *$ & -0.3 & 6.66 & 0.03 & 3.21 & $10.59 *$ \\
\hline CDD & $-2.26^{*}$ & $-2.68 *$ & $-4.85^{*}$ & $-5.0 *$ & $-4.64 *$ & -0.05 & -1.22 & -0.05 \\
\hline CWD & 0.28 & 1.70 & $0.047 *$ & & -0.07 & $-0.08 *$ & & \\
\hline $\mathrm{R} 10 \mathrm{~mm}$ & $2.19 *$ & $2.67 *$ & $0.22 *$ & -0.03 & 0.23 & 0 & & \\
\hline $\mathrm{R} 20 \mathrm{~mm}$ & 1.94 & $2.97 *$ & & & & 0 & & \\
\hline Rx1 day & $2.14 *$ & 0.77 & $0.63 *$ & 0 & 0.27 & $0.05 *$ & 1.37 & $0.85 *$ \\
\hline Rx5 day & 1.50 & $1.85^{*}$ & $0.98 *$ & 0 & -0.08 & 0.03 & 1.90 & 0.55 \\
\hline $\begin{array}{c}\text { Data } \\
\text { Source }\end{array}$ & This study & $\begin{array}{c}\text { Zhang et al. } \\
\text { (2017) }\end{array}$ & $\begin{array}{c}\text { Wang et al. } \\
\text { (2013a) }\end{array}$ & $\begin{array}{c}\text { Zhang et al. } \\
\quad(2005)\end{array}$ & $\begin{array}{l}\text { You et al. } \\
(2008)\end{array}$ & $\begin{array}{l}\text { Li et al. } \\
\text { (2012) }\end{array}$ & $\begin{array}{c}\text { You et al. } \\
\text { (2011) }\end{array}$ & $\begin{array}{c}\text { Alexander } \\
\text { et al. (2006) }\end{array}$ \\
\hline
\end{tabular}

Trends significant (significance level $<0.05$ ) are marked with *.

The above analysis indicates that total precipitation and precipitation extremes exhibited increasing trends in the five countries of Central Asia, as well as in northwest China, the 
eastern and central Tibetan Plateau, western Argentina, and Australia. At the same time, total precipitation and heavy precipitation showed decreasing trends in the southwestern United States, the west coast of South America, the Greater Horn of Africa region, the Middle East, and the Arabian Peninsula. Meanwhile, CDD or droughts showed rising trends in the west coast of South America, Australia, southwestern United States, the Greater Horn of Africa region and the Arabian Peninsula, while CDD or droughts experienced falling trends only in the five countries of CA (Zhang et al., 2017), northwest China (Wang et al., 2013a; Wang et al., 2013b; Chen et al., 2014; Chen et al., 2015), the Middle East, the eastern and central Tibetan Plateau, and western Argentina. From these findings, we can see that there are uncertainties in total precipitation and dry-humid variations, which may differ in arid regions under climate change. This conclusion is consistent with the findings of Greve et al. (2014) and Donat et al. (2016), which also demonstrated that drier and wetter trends differed across regions. Thus, the question "Is Central Asia getting drier?", which was raised more than half a century ago (Markov et al., 1951), is still an exploratory subject that requires more discussion across different periods.

In recent years, several scholars concluded that anthropogenic activities formed the root causes of variations in climate change and ECEs (Kim et al., 2016; Stott, 2016; Stott et al., 2016; Chen and Sun, 2017; Diffenbaugh et al., 2017). Anthropogenic activities can also influence changes in atmospheric circulation, which is another aspect of climate change. Therefore, it is necessary to conduct research on the associations between climate extremes and atmospheric circulation. Within the CA region, which includes the five countries of CA as well as northwestern China, some studies showed that mean and climate extremes were closely related to the movements of the westerly jet stream (Chen et al., 2008; Cheng et al., 2016; Wei et al., 2017), the South Asian High (Wei et al., 2017), the Asian monsoon (Zhang et al., 2002; Cheng et al., 2016), SH (Li et al., 2012), TPI_B (Chen et al., 2014), West Pacific Subtropical High, and the North American Subtropical High (Li et al., 2016a). In this study, we detected that SH and WCI had a significant correlation with temperature extremes, while TPI_B and PNA had good consistency with precipitation extremes. In fact, according to comparisons of the significance levels of both temperature and precipitation extremes, we believe that SH and TPI_B might be the most important atmospheric circulation factors affecting climate extremes, a finding which is consistent with previous studies (Li et al., 2012; Chen et al., 2014).

Through its influence on atmospheric circulation, the Tibetan Plateau plays a critical role in the climate formation in Asia and the surrounding areas. To reflect the activities of high pressure and low vortex at $500 \mathrm{hPa}$ over the Tibetan Plateau, TPI_B is adopted into the climate research. TPI_B ranges from $30^{\circ} \mathrm{N}$ to $40^{\circ} \mathrm{N}$ and $75^{\circ} \mathrm{E}$ to $105^{\circ} \mathrm{E}$, and is defined as an accumulative value of the $500 \mathrm{hPa}$ height value minus 500 dagpm (Chen et al., 2014). In our study area, TPI_B showed significant relations with all precipitation extremes (Prcptot, CDD, CWD, R10, R20, Rx1 and Rx5) and three temperature extremes (Tav, Tnav and ID0). This result was consistent with the result of Chen et al. (2014) in northwestern China, which revealed that TPI_B was highly correlated with Pav (annual mean precipitation), Tav, Tnav and Txav.

$\mathrm{SH}$ is a very dry cold air mass which forms in the Mongolian-Siberian region. It has a great influence on the weather patterns and climate in most of the Northern Hemisphere, especially continental Asia (Cohen et al., 2001; Gong and Ho, 2002; Jeong et al., 2011; Li et 
al., 2012). In Eurasia, SH is the crucial atmospheric center of action during winter and thus has close associations with winter temperatures. Gong and Ho (2002) showed that SH was relatively strong in the 1960s but weakened substantially from the late 1970 s to the 1990 s. Jeong et al. (2011) revealed that SH intensity (SHI) exhibited a notable weakening trend during the 1970s and 1980s. In the 1990s, it showed the lowest SHI but recovered rapidly into the 2000s. The reason for the strengthening of the SHI was the increase in Eurasian snow cover in the 1990s and 2000s and the near-surface cooling over the SH central region. In this study, the extreme temperature indices of Tav, Txav, Tnav, FD0, ID0, TXn and TNn in $\mathrm{CA}$ had significant correlations with $\mathrm{SH}$ and showed warm nights and warm winter trends.

\section{Conclusions}

In this study, we detected spatial-temporal variation trends and abrupt changes in climate extremes in Central Asia based on daily climate observations across regional monitoring stations during 1957-2005. We also speculated on possible atmospheric circulation factors impacting the climate extremes of CA. Several conclusions are drawn from this study as follows:

(1) During 1957-2005, the annual mean temperature and temperature extremes in CA had widespread significant warming trends, especially for those indices derived from daily minimum temperature, which showed higher warming rates. The rise in minimum temperature was the main driving force in climate warming in CA. In this study, Tav significantly increased at a rate of $0.032^{\circ} \mathrm{C} / \mathrm{a}$, which was far higher than the increasing rates globally and in the Northern Hemisphere. The changing rate of Txav, Tnav, TXx, TNx, SU25, TXn, TNn, FD0 and ID0 was $0.024^{\circ} \mathrm{C} / \mathrm{a}, 0.041^{\circ} \mathrm{C} / \mathrm{a}, 0.020^{\circ} \mathrm{C} / \mathrm{a}, 0.030^{\circ} \mathrm{C} / \mathrm{a}, 0.206$ days $/ \mathrm{a}, 0.059^{\circ} \mathrm{C} / \mathrm{a}$, $0.088^{\circ} \mathrm{C} / \mathrm{a},-0.323$ days/a and -0.187 days/a, respectively. The results indicated that higher extreme temperature values had significantly increased, while colder extreme temperature values had significantly decreased. During 1957-2005, the abrupt change of Tav, Txav, Tnav, TXx, TNx, SU25, TXn, TNn, FD0 and ID0 occurred around 1987, 1987, 1977, 1972, 1973, 1973, 1978, 1978, 1976 and 1986, respectively. Furthermore, Tav and temperature extremes exhibited spatially widespread rising trends with slight spatial variations. In particular, an overall warming trend was noted in the Tianshan Mountains, northern Xinjiang and Kazakhskiy Melkosopochnik.

(2) Compared to temperature changes, annual mean precipitation and extremes in CA were generally less consistent and significant during 1957-2005. Prcptot significantly increased at a rate of $0.476 \mathrm{~mm} / \mathrm{a}$, while precipitation extremes increased slightly. The changing rate of $\mathrm{CDD}, \mathrm{CWD}, \mathrm{R} 10, \mathrm{R} 20, \mathrm{Rx} 1$ and $\mathrm{Rx} 5$ was -0.317 days/a, 0.001 days/a, 0.016 days/a, 0.004 days $/ \mathrm{a}, 0.040 \mathrm{~mm} / \mathrm{a}$ and $0.055 \mathrm{~mm} / \mathrm{a}$, respectively. All of the precipitation indices experienced an abrupt change in 1986 and all precipitation extremes showed spatial diversity and heterogeneity. Wetter trends and precipitation extremes increased in the Tianshan Mountains, Kazakhskiy Melkosopochnik, the Kyzylkum Desert and most of Xinjiang, while drier trends and decreased precipitation extremes emerged in the West Siberian Plain and the Turgay Valley.

(3) Through Spearman's correlation analysis, we detected that SH and WCI had significant correlations with temperature extremes, and TPI_B and PNA had good consistency with 
precipitation extremes. SH showed significant correlation with Tav, Txav, Tnav, FD0, ID0, TXn, TNn and Prcptot, and TPI_B had good consistency with Tav, Tnav, ID0, Prcptot, CDD, CWD, R10, R20, Rx1 and Rx5. According to the comparison of significance levels using both temperature and precipitation extremes, we concluded that SH and TPI_B are likely the most important atmospheric circulation factors affecting the climate extremes in this study.

\section{References}

Aizen V B, Kuzmichenok V A, Surazakov A B et al., 2006. Glacier changes in the central and northern Tien Shan during the last 140 years based on surface and remote-sensing data. Annals of Glaciology, 43(1): 202-213. doi: $10.3189 / 172756406781812465$.

Alexander L V, 2016. Global observed long-term changes in temperature and precipitation extremes: A review of progress and limitations in IPCC assessments and beyond. Weather and Climate Extremes, 11: 4-16. doi: 10.1016/j.wace.2015.10.007.

Alexander L V, Arblaster J M, 2009. Assessing trends in observed and modelled climate extremes over Australia in relation to future projections. International Journal of Climatology, 29: 417-435. doi: 10.1002/joc.1730.

Alexander L V, Zhang X, Peterson, T C et al., 2006. Global observed changes in daily climate extremes of temperature and precipitation. Journal of Geophysical Research, 111: D5. doi: 10.1029/2005jd006290.

Bothe O, Fraedrich K, Zhu X H, 2012. Precipitation climate of Central Asia and the large-scale atmospheric circulation. Theoretical and Applied Climatology, 108: 345-354. doi: 10.1007/s00704-011-0537-2.

Buishand T A, 1982. Some methods for testing the homogeneity of rainfall records. Journal of Hydrology, 58: 11-27. doi: 10.1016/0022-1694(82)90066-X.

Chen F H, Wang J S, Jin L Y et al., 2009. Rapid warming in mid-latitude Central Asia for the past 100 years. Frontiers of Earth Science in China, 3: 42-50. doi: 10.1007/s11707-009-0013-9.

Chen F H, Yu Z, Yang M et al., 2008. Holocene moisture evolution in arid Central Asia and its out-of-phase relationship with Asian monsoon history. Quaternary Science Reviews, 27: 351-364. doi: 10.1016/j.quascirev. 2007.10.017.

Chen H P, Sun, J Q, 2017. Anthropogenic warming has caused hot droughts more frequently in China. Journal of Hydrology, 544: 306-318. doi: 10.1016/j.jhydrol.2016.11.044.

Chen Y N, Deng H J, Li B F et al., 2014. Abrupt change of temperature and precipitation extremes in the arid region of Northwest China. Quaternary International, 336: 35-43. doi: 10.1016/j.quaint.2013.12.057.

Chen Y N, Li Z, Fan Y T et al., 2015. Progress and prospects of climate change impacts on hydrology in the arid region of Northwest China. Environmental Research, 139: 11-19. doi: 10.1016/j.envres.2014.12.029.

Chen Y N, Li Z, Li W H et al., 2016. Water and ecological security: Dealing with hydroclimatic challenges at the heart of China's Silk Road. Environmental Earth Sciences, 75: 881. doi: 10.1007/s12665-016-5385-z.

Cheng H, Spötl C, Breitenbach S F M et al., 2016. Climate variations of Central Asia on orbital to millennial timescales. Scientific Reports, 6: 36975. doi: 10.1038/srep36975.

Cohen J, Saito K, Entekhabi D, 2001. The role of the Siberian High in Northern Hemisphere climate variability. Geophysical Research Letters, 28: 299-302. doi: 10.1029/2000GL011927.

Deng H J, Chen Y N, Shi X et al., 2014. Dynamics of temperature and precipitation extremes and their spatial variation in the arid region of Northwest China. Atmospheric Research, 138: 346-355. doi: 10.1016/j.atmosres.2013.12.001.

Diffenbaugh N S, Singh D, Mankin J S et al., 2017. Quantifying the influence of global warming on unprecedented extreme climate events. Proceedings of the National Academy of Sciences, 114: 4881-4886. doi: 10.1073/pnas.1618082114.

Donat M G, Lowry A L, Alexander L V et al., 2016. More extreme precipitation in the world's dry and wet regions. Nature Climate Change, 6: 508-513. doi: 10.1038/NCLIMATE2941.

Donat M G, Peterson T C, Brunet M et al., 2014. Changes in extreme temperature and precipitation in the Arab region: Long-term trends and variability related to ENSO and NAO. International Journal of Climatology, 34: 581-592. doi: 10.1002/joc.3707.

Dugmore A J, Borthwick D M, Church M J et al., 2007. The role of climate in settlement and landscape change in the North Atlantic Islands: An assessment of cumulative deviations in high-resolution proxy climate records. Human Ecology, 35: 169-178. doi: 10.1007/s10745-006-9051-z.

Easterling D R, Meehl G A, Parmesan C et al., 2000. Climate extremes: Observations, modeling, and impacts. Science, 289, 2068-2074. doi: 10.1126/science.289.5487.2068.

Frachetti M D, Smith C E, Traub C M et al., 2017. Nomadic ecology shaped the highland geography of Asia's Silk Roads. Nature, 543: 193-198. doi: 10.1038/nature21696.

Gong D Y, Ho C H, 2002. The Siberian High and climate change over middle to high latitude Asia. Theoretical 
and applied climatology, 72(1): 1-9. doi: 10.1007/s007040200008.

Greve P, Orlowsky B, Mueller B et al., 2014. Global assessment of trends in wetting and drying over land. Nature Geoscience, 7: 716-721. doi: 10.1038/NGEO2247.

Hansen J, Ruedy R, Sato M et al., 2010. Global surface temperature change. Reviews of Geophysics, 48: RG4004. doi: $10.1029 / 2010 \mathrm{RG} 000345$.

Harris I P D J, Jones P D, Osborn T J et al., 2014. Updated high-resolution grids of monthly climatic observations: The CRU TS3. 10 Dataset. International Journal of Climatology, 34(3): 623-642. doi: 10.1002/joc.3711.

Herold N, Behrangi A, Alexander L V, 2017. Large uncertainties in observed daily precipitation extremes over land. Journal of Geophysical Research: Atmospheres, 122: 668-681. doi: 10.1002/2016JD025842.

Howard K W F, Howard K K, 2016. The new "Silk Road Economic Belt" as a threat to the sustainable management of Central Asia's transboundary water resources. Environmental Earth Sciences, 75: 976. doi: $10.1007 / \mathrm{s} 12665-016-5752-9$.

$\mathrm{Hu} \mathrm{Z}, \mathrm{Hu} \mathrm{Q}$, Zhang C et al., 2016. Evaluation of reanalysis, spatially interpolated and satellite remotely sensed precipitation data sets in Central Asia. Journal of Geophysical Research: Atmospheres, 121: 5648-5663. doi: 10.1002/2016JD024781.

Hu Z Y, Zhang C, Hu Q et al., 2014. Temperature changes in Central Asia from 1979 to 2011 based on multiple datasets. Journal of Climate, 27: 1143-1167.

IPCC, 2012. Managing the risks of extreme events and disasters to advance climate change adaptation. In: Field C B, Barros V, Stocker T F et al. A Special Report Working Groups I and II of the Intergovernmental Panel on Climate Change. Cambridge, UK, and New York, NY, USA: Cambridge University Press, 109-290.

IPCC, 2013: Summary for policymakers. In: Climate Change 2013: The Physical Science Basis. Contribution of Working Group I to the Fifth Assessment Report of the Intergovernmental Panel on Climate Change. In: Stocker T F, Qin D, Plattner G-K et al. eds. Cambridge, United Kingdom and New York, NY, USA: Cambridge University Press.

Jeong J-H, Ou T, Linderholm H W et al., 2011. Recent recovery of the Siberian High intensity. Journal of Geophysical Research: Atmospheres, 116: D23102. doi: 10.1029/2011JD015904.

Jones P D, Lister D H, Osborn T J et al., 2012. Hemispheric and large-scale land-surface air temperature variations: An extensive revision and an update to 2010. Journal of Geophysical Research: Atmospheres, 117: D05127.

Karl T R, Easterling D R, 1999. Climate extremes: Selected review and future research directions. Climatic Change, 42: 309-325. doi: 10.1007/978-94-015-9265-9_17.

Kendall M G, 1975. Rank Correlation Measures. London: Charles Griffin, 202.

Kim Y H, Min S K, Zhang X et al., 2016. Attribution of extreme temperature changes during 1951-2010. Climate Dynamics, 46(5/6): 1769-1782. doi: 10.1007/s00382-015-2674-2.

King A D, Alexander L V, Donat M G, 2013. The efficacy of using gridded data to examine extreme rainfall characteristics: A case study for Australia. International Journal of Climatology, 33: 2376-2387. doi: $10.1002 /$ joc. 3588 .

Klein Tank A M G, Peterson T C, Quadir D A et al., 2006. Changes in daily temperature and precipitation extremes in Central and South Asia. Journal of Geophysical Research, 111: D16105. doi: 10.1029/ 2005JD006316.

Li B F, Chen Y N, Chen Z S et al., 2016a. Why does precipitation in Northwest China show a significant increasing trend from 1960 to 2010? Atmospheric Research, 167: 275-284. doi: 10.1016/j.atmosres. 2015.08.017.

Li B F, Chen Y N, Shi X, 2012. Why does the temperature rise faster in the arid region of Northwest China? Journal of Geophysical Research: Atmospheres, 117: D16115. doi: 10.1029/2012JD017953.

Li P Y, Qian H, Howard K W F et al., 2015a. Building a new and sustainable "Silk Road Economic Belt". Environmental Earth Sciences, 74: 7267. doi: 10.1007/s12665-015-4739-2.

Li P Y, Qian H, Zhou W, 2017. Finding harmony between the environment and humanity: An introduction to the thematic issue of the Silk Road. Environmental Earth Sciences, 76: 105. doi: 10.1007/s12665-017-6428-9.

Li Z, Chen Y N, Li W H et al., 2015b. Potential impacts of climate change on vegetation dynamics in Central Asia. Journal of Geophysical Research: Atmospheres, 120: 12345-12356. doi: 10.1002/2015JD023618.

Li Z, Chen Y N, Wang Y et al., 2016b. Drought promoted the disappearance of civilizations along the ancient Silk Road. Environmental Earth Sciences, 75: 1116. doi: 10.1007/s12665-016-5925-6.

Lioubimtseva E, Cole R, Adams J M et al., 2005. Impacts of climate and land-cover changes in arid lands of Central Asia. Journal of Arid Environments, 62: 285-308. doi: 10.1016/j.jaridenv.2004.11.005.

Lioubimtseva E, Henebry G M, 2009. Climate and environmental change in arid Central Asia: Impacts, vulnerability, and adaptations. Journal of Arid Environments, 73: 963-977. doi: 10.1016/j.jaridenv. 2009.04.022.

Liu M X, Xu X L, Sun A Y et al., 2014. Is southwestern China experiencing more frequent precipitation extremes? Environmental Research Letters, 9: 064002. doi: 10.1088/1748-9326/9/6/064002.

Mann H B, 1945. Non-parametric tests against trend. Econometrica, 13: 245-259. 
Mannig B, Müller M, Starke E et al., 2013. Dynamical downscaling of climate change in Central Asia. Global and Planetary Change, 110: 26-39. doi: 10.1016/j.gloplacha.2013.05.008.

Markov K V, 1951. Is Middle and Central Asia getting drier? Geografgiz, 24: 98-116.

Menne M J, Durre I, Vose R S et al., 2012. An overview of the Global Historical Climatology Network-Daily Database. Journal of Atmospheric and Oceanic Technology, 29: 897-910.

Morice C P, Kennedy J J, Rayner N A et al., 2012. Quantifying uncertainties in global and regional temperature change using an ensemble of observational estimates: The HadCRUT4 data set. Journal of Geophysical Research: Atmospheres, 117: D08101. doi: 10.1029/2011JD017187.

Nunes A N, Lourenço L, 2015. Precipitation variability in Portugal from 1960 to 2011. Journal of Geographical Sciences, 25(7): 784-800.

Omondi P A, Awange J L, Forootan E et al., 2014. Changes in temperature and precipitation extremes over the Greater Horn of Africa region from 1961 to 2010. International Journal of Climatology, 34(4): 1262-1277. doi: $10.1002 /$ joc. 3763 .

Peterson T C, Heim R R, Hirsch R et al., 2013. Monitoring and understanding changes in heat waves, cold waves, floods, and droughts in the United States: State of knowledge. Bulletin of the American Meteorological Society, 94(6): 821-834. doi: 10.1175/BAMS-D-12-00066.1.

Pritchard H D, 2017. Asia's glaciers are a regionally important buffer against drought. Nature, 545: 169-174. doi: 10.1038/nature22062.

Schiemann R, Lüthi D, Vidale P L et al., 2008. The precipitation climate of Central Asia: Intercomparison of observational and numerical data sources in a remote semiarid region. International Journal of Climatology, 28: 295-314. doi: 10.1002/joc.1532.

Skansi M d 1 M, Brunet M, Sigró J et al., 2013. Warming and wetting signals emerging from analysis of changes in climate extreme indices over South America. Global and Planetary Change, 100: 295-307. doi: 10.1016/j.gloplacha.2012.11.004.

Stott P A, 2016. How climate change affects extreme weather events. Science, 352: 1517-1518. doi: 10.1126/science.aaf7271.

Stott P A, Christidis N, Otto F E L et al., 2016. Attribution of extreme weather and climate-related events. Wiley Interdisciplinary Reviews: Climate Change, 7(1): 23-41. doi: 10.1002/wcc.380.

Trenberth K E, Fasullo J T, Shepherd T G, 2015. Attribution of climate extreme events. Nature Climate Change, 5: 725-730. doi: 10.1038/nclimate2657.

Wang H J, Chen Y N, Chen Z S, 2013a. Spatial distribution and temporal trends of mean precipitation and extremes in the arid region, northwest of China, during 1960-2010. Hydrological Processes, 27: 1807-1818. doi: 10.1002/hyp.9339.

Wang H J, Chen Y N, Shi X et al., 2013b. Changes in daily climate extremes in the arid area of northwestern China. Theoretical and Applied Climatology, 112: 15-28. doi: 10.1007/s00704-012-0698-7.

Wei W, Zhang R H, Wen M et al., 2017. Relationship between the Asian westerly jet stream and summer rainfall over Central Asia and North China: Roles of the Indian Monsoon and the South Asian High. Journal of Climate, 30: 537-552. doi: 10.1175/JCLI-D-15-0814.1.

Westra S, Alexander L V, Zwiers F W, 2013. Global increasing trends in annual maximum daily precipitation. Journal of Climate, 26: 3904-3918. doi: 10.1175/JCLI-D-12-00502.1.

Yatagai A, Kamiguchi K, Arakawa $\mathrm{O}$ et al., 2012. Constructing a long-term daily gridded precipitation dataset for Asia based on a dense network of rain gauges. Bulletin of the American Meteorological Society, 93: 1401-1415. doi: 10.1175/BAMS-D-11-00122.1.

You Q L, Kang S C, Aguilar E et al., 2008. Changes in daily climate extremes in the eastern and central Tibetan Plateau during 1961-2005. Journal of Geophysical Research: Atmospheres, 113: D07101. doi: 10.1029/ 2007jd009389.

You Q L, Kang S C, Aguilar E et al., 2011. Changes in daily climate extremes in China and their connection to the large scale atmospheric circulation during 1961-2003. Climate Dynamics, 36: 2399-2417. doi: 10.1007/s00382-009-0735-0.

Zhang C J, Xie J N, Li D L et al., 2002. Effect of East-Asian monsoon on drought climate of Northwest China. Plateau Meteorology, 21(2): 193-198. (in Chinese)

Zhang M, Chen Y N, Shen Y J et al., 2017. Changes of precipitation extremes in arid Central Asia. Quaternary International, 436: 16-27. doi: 10.1016/j.quaint.2016.12.024.

Zhang X B, Aguilar E, Sensoy S et al., 2005. Trends in Middle East climate extreme indices from 1950 to 2003. Journal of Geophysical Research: Atmospheres, 110: D22. doi: 10.1029/2005JD006181.

Zhang X B, Feng Y, 2004. R ClimDex (1.0). User Manual. Climate research branch environment Canada Downsview, Ontario Canada.

Zhang X B, Wan H, Zwiers F W et al., 2013. Attributing intensification of precipitation extremes to human influence. Geophysical Research Letters, 40: 5252-5257. doi: 10.1002/grl.51010. 